\title{
Multiple pathways towards achieving a living income for different types of smallholder tree-crop commodity farmers
}

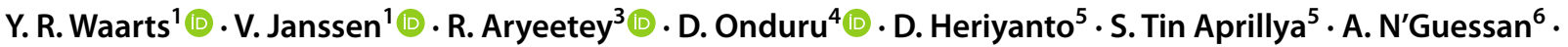

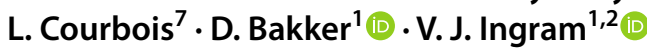

Received: 17 March 2021 / Accepted: 11 August 2021/ Published online: 18 October 2021

(c) The Author(s) 2021

\begin{abstract}
Many sources indicate that smallholder tree-crop commodity farmers are poor, but there is a paucity of data on how many of them are poor and the depth of poverty. The living income concept establishes the net annual income required for a household in a place to afford a decent standard of living. Based on datasets on smallholder cocoa and tea farmers in Ghana, Ivory Coast and Kenya and literature, we conclude that a large proportion of such farmers do not have the potential to earn a living income based on their current situation. Because these farmers typically cultivate small farm sizes and have low capacity to invest and to diversify, there are no silver bullets to move them out of poverty. We present an assessment approach that results in insights into which interventions can be effective in improving the livelihoods of different types of farmers. While it is morally imperative that all households living in poverty are supported to earn a living income, the assessment approach and literature indicate that focussing on short- to medium-term interventions for households with a low likelihood of generating a living income could be: improving food security and health, finding off-farm and alternative employment, and social assistance programmes. In the long term, land governance policies could address land fragmentation and secure rights. Achieving living incomes based on smallholder commodity production requires more discussion and engagement with farmers and their household members and within their communities, coordination between all involved stakeholders, sharing lessons learnt and data.
\end{abstract}

Keyword Smallholder commodity farmers $\cdot$ Poverty benchmarks $\cdot$ Living income $\cdot$ Behavioural change $\cdot$ Land governance . Social assistance programme

This article belongs to the Topical Collection: Food System Transformations for Healthier Diets, Inclusive Livelihoods and Sustainable Environment

Guest Editors: Romina E Cavatassi, Leslie Lipper, Ruerd Ruben, Eric Smaling, Paul Winters

Y. R. Waarts

yuca.waarts@wur.nl

1 Wageningen Economic Research, Wageningen University and Research (WUR), P.O. Box 29703, 2502 LS The Hague, The Netherlands

2 Forest \& Nature Conservation Policy Group, Wageningen University and Research (WUR), Wageningen, The Netherlands

3 School of Public Health, University of Ghana, Legon, Ghana

4 ETC Consultants, Nairobi, Kenya

\section{The living income concept in the context of smallholder tree-crop commodity production}

\subsection{Smallholder tree-crop commodity production, poverty and intervention impacts}

\subsubsection{Millions of smallholder tree-crop commodity farmers produce the raw material for tea, coffee, chocolate and other products, and many of them are poor}

Millions of people globally, including many smallholder farmers, earn a revenue from the cultivation or processing of agricultural commodities, particularly tree-crops such as cocoa, coffee,

\footnotetext{
CIRCLE Indonesia, Yogyakarta, Indonesia

6 EMC - Etudes de Marche Et Conseils, Abidjan, Ivory Coast

7 Imani Development, Blantyre, Malawi
} 
Table 1 Overview of the number of people earning a revenue from commodity production and processing

\begin{tabular}{llll}
\hline Sector & $\begin{array}{l}\text { Number of people earning } \\
\text { revenue from cultivation and } \\
\text { processing }\end{array}$ & $\begin{array}{l}\text { Total number of farming } \\
\text { households }\end{array}$ & $\begin{array}{l}\text { Share of smallholder farmers in total number of } \\
\text { farming households }\end{array}$ \\
\hline Cocoa (Voora et al., 2019a) & $40-50$ million & 5 million & $70 \%(3.5$ million) \\
Coffee (Voora et al., 2019b) & 125 million & 12.5 million & $67-80 \%(8.4-10 \text { million })^{*}$ \\
Oil palm (Voora et al., 2019d) & About 6 million & & 3 million smallholders \\
Tea (Voora et al., 2019c) & Over 13 million & & 9 million smallholders \\
& & & $70 \%$ of global production comes from 8 million \\
smallholder farmers in Asia and Africa
\end{tabular}

*Author's calculations based on (Voora et al., 2019a, b, c, d)

cotton, oil palm and tea (Voora et al., 2019a, b, c, d, 2020a, b) (Table 1). Tree crops, given their long maturation and system lifecycles, have particular distinguishing farming and farmer system characteristics (Ingram, 2021). Commodity production and processing are thus important economic activities within local food systems. The production of these crops largely takes place in lower- and middle-income countries; throughout the literature, it is clear that many of the smallholder farmers in these commodity sectors are poor (Voora et al., 2019a, b, c, d, 2020a, b). They have no control over global market prices and are often hampered by limited negotiating power. They are vulnerable to price changes in markets as well as climate change (International Food Policy Research Institute (IFPRI), 2020). In times of oversupply and market speculation, commodity prices can fall below the cost of production so that smallholder farmers cannot break even. Prolonged periods of low prices can have a disastrous effect on farmers' livelihoods and on the long-term sustainability of commodity supply. Poverty adversely affects human wellbeing and development, including productivity, and overcoming it remains a central focus of global sustainable development goals (United Nations, 2020).

\subsubsection{To date, the success of interventions aimed at reducing poverty levels of smallholder commodity farmers has been limited}

Many different types of interventions have been implemented in tree-crop commodity value chains in the past two decades, by private and public sector, and non-governmental organisations. Most interventions have focused on improving productivity or enhancing local capacities or structures (Ingram et al., 2018). Examples of such interventions are training on agricultural practices, voluntary sustainability certification, provision of free or subsidised inputs such as seeds and fertiliser, support to farmer groups, communitylevel provision of infrastructure, and access to finance. But such interventions generally have either not lifted smallholder farmers out of poverty, or their effectiveness has not been documented, as most interventions that have been documented have had limited, mixed or no impact on household incomes (Alvarez \& Von Hagen, 2011; Dalberg \& Wageningen University, 2018; Ingram et al., 2014, 2018; Oya et al., 2017; Waarts et al., 2015, 2016; Woodhill et al., 2020).

\subsection{The living income concept and how it is used}

\subsubsection{The concept of living income embraces 'a decent standard of living' for households}

World Bank poverty lines are commonly used to assess poverty levels and compare countries, especially, the extreme poverty line of USD 1.90 (2011 PPP). But stakeholder groups increasingly realise that such poverty lines are not an indication of whether farmers have a decent standard of living. Instead, the aim of poverty measurements should be to focus on empowering people to have a 'decent standard of living' (Minos, 2018). This is connected to clause 25 of the Universal Declaration of Human Rights that states that: 'Everyone has the right to a standard of living adequate for the health and well-being of himself and of his family, including food, clothing, housing and medical care and necessary social services, and the right to security in the event of unemployment, sickness, disability, widowhood, old age or other lack of livelihood in circumstances beyond his control'. Due to the growing interest of donors, NGOs, policy makers, and other parties to achieve a decent standard of living, the World Bank poverty benchmarks are gradually being replaced with 'living income' and 'living wage' benchmarks in commodity sectors, to assess poverty levels and impact of interventions on poverty. A living income is defined as 'the net annual required for a household in a particular place to afford a decent standard of living for all members of that household' (Anker \& Anker, 2017) (Fig. 1). A 'decent standard of living' includes: a nutritious lowcost diet based on nutritional requirements and local food preferences, housing that meets local norms and common international standards of decency, essential needs including healthcare, clothing, education and transport, and a margin for unforeseen events (Anker \& Anker, 2017; Grillo, 2018). The margin for unforeseen events anticipates and plans for 
Fig. 1 The living income concept. Source: Living Income Community of Practice: www. living-income.com

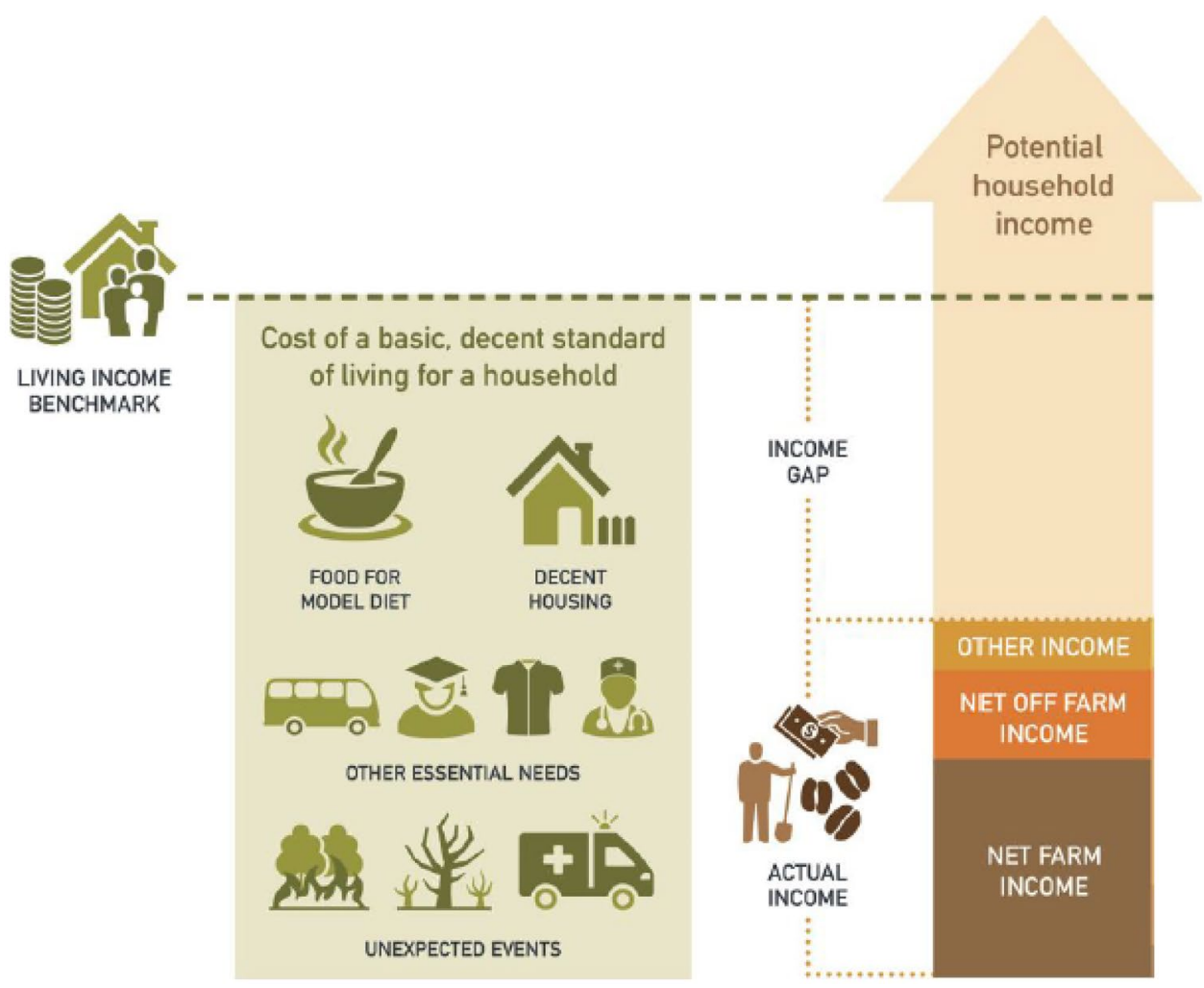

resilient livelihoods. Whereas living wages focus more on wages from single sources (e.g. factory workers), the living income concept considers all sources of income for the entire household.

\subsubsection{To assess the extent farmers earn a living income, information on actual total net household income levels is needed, and a living income benchmark needs to be established}

To know what a living income is, a living income benchmark is established for a specific country, or region within a country. The circumstances within a particular year or season, cost of living, price changes over time, and inflation are considered. A living income benchmark thus indicates what a typical household minimally needs to have 'a decent life', based on the cost of a basic, decent standard of living for that household. Such benchmarks are often linked to a specific sector and/or a certain location. To establish this benchmark, information is collected from national and regional statistics and/or field research is conducted to obtain information (CIRES, 2018; van de Ven et al., 2020). To calculate the gap between actual incomes and a living income, the actual net household income per household member per day is deducted from the living income benchmark per household member per day (COSA and KIT, n.d.; Impact Institute, n.d.) ${ }^{1}$. The formula to calculate the gap between the living income benchmark and actual household income is shown in Formula 1. It should be mentioned that even if the living income concept is an entire household concept, it may be that even if a household earns a living income, such income and benefits stemming from the income, are not divided equally between all household members. This should be addressed in conducting living income assessments.

Formula 1 The formula for calculating the living income gap

LI : Living income benchmark per person per year

$=\frac{\text { Living income benchmark per month for a typical household } * 12}{\text { Number of typical household members }}$

AI : Actual total net household income per person per year

$=\frac{\text { Actual total net income per household per year }}{\text { Number of household members }}$

Living income gap per person per day $: \frac{L I-A I}{365}$

\footnotetext{
${ }^{1}$ In the actual net income measurement, food produced by the household and used for home-consumption is taken into account, as many smallholder farmers consume food produced by themselves.
} 


\subsection{The food systems approach}

\subsubsection{In the food system, income is interlinked, often nonlinearly, with food and nutrition security}

Food and nutrition are both influenced by and influence health, labour availability, household decision-making, yields and incomes (Walton et al., 2020) as well as farm productivity (Arsyad et al., 2019; Fisher \& Hostland, 2002). A food systems approach, defined as all the processes involved in achieving desired food system outcomes, including but not limited to food security for a specific population (Fig. 2), is the framing concept used to examine living incomes and poverty levels. This is due to the strong effect of household incomes on food security outcomes (Babatunde \& Qaim, 2010; Iram \& Butt, 2004; Kennedy \& Peters, 1992). Poverty status and the living income concept are used as a lens to focus on smallholder tree-crop commodity farmer household incomes as socio-economic food system outcomes.

\subsubsection{In a food system, contextual and personal factors influence farmer's decision making and behaviour}

Within a food system, contextual factors (shown in Fig. 3) and personal factors, can strongly differ between farmers and geographies (van Berkum et al., 2018; Waarts et al., 2019). These factors have important implications for farmers' income from agricultural production and off-farm activities, which is why we present the two figures additionally to the food systems figure above as it deepens the information for food system components which are important for tree-crop commodity farmer income. Regarding contextual factors, what works best in one place, might not work in another place. Some of the key recurring barriers to behavioural change are: 1) Farmers might not be able to afford the financial investments that are required for technological innovations, or might decide to invest in something else, 2) The future benefits of investments are not guaranteed, 3 ) Failing markets lead to adoption constraints (i.e. shortage of inputs when needed), 4) Interventions may not be tailored enough to farmers' specific needs and possibilities (Waarts et al., 2019). Interventions that address these barriers are therefore more likely to lead to behavioural change of farmers and therefore positively impact incomes.

\subsubsection{Personal factors also influence whether farmers will adopt certain technologies or participate in interventions}

Frequently, interventions have been implemented from a technocratic perspective which does not consider personal factors. Studies have shown that these factors influence farmer and household decision-making processes (Waarts et al., 2019). Personal factors include socio-economic

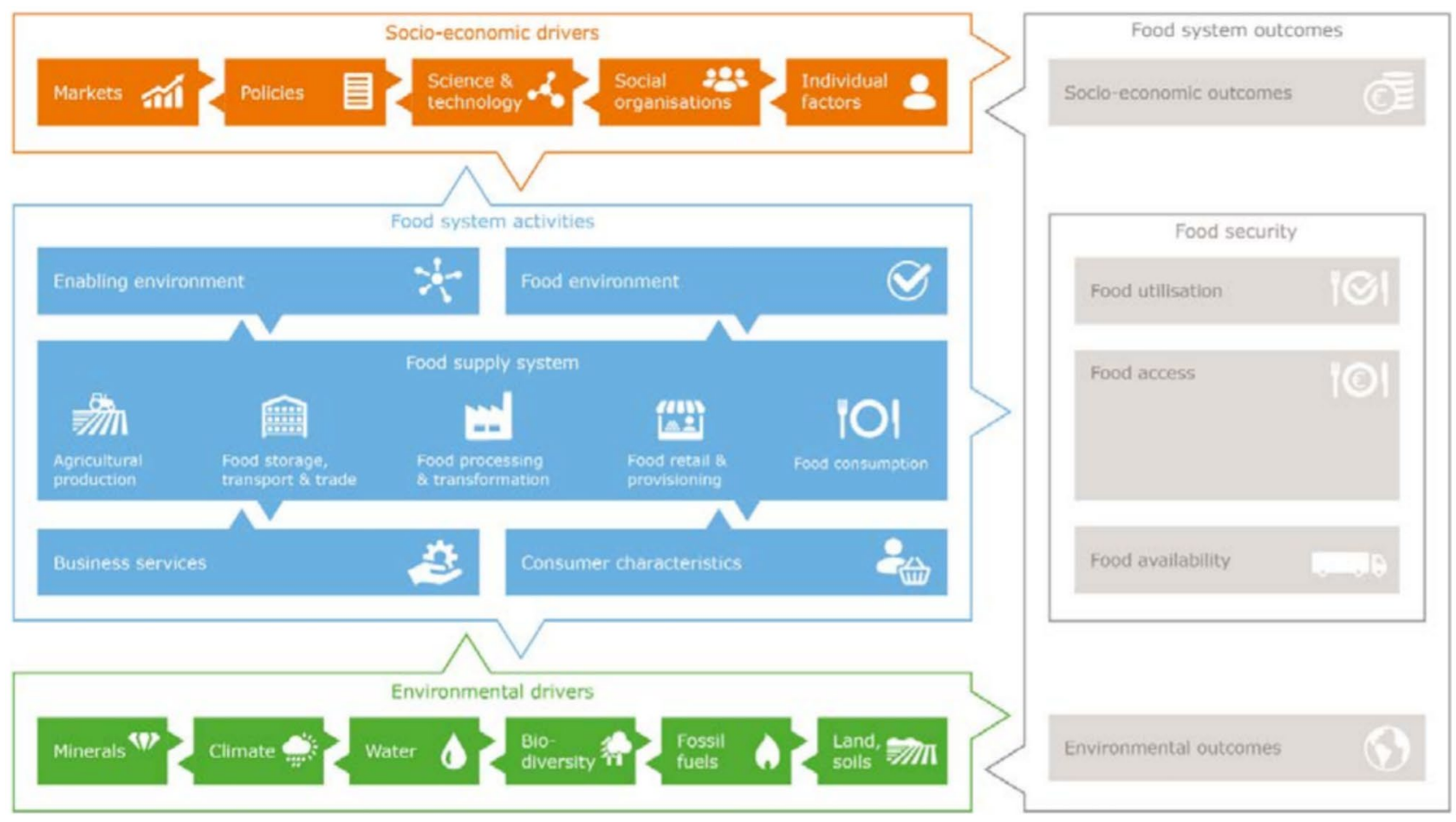

Fig. 2 The food system, its drivers and outcomes. Source: (van Berkum et al., 2018) 
Fig. 3 Key contextual factors in the design of living income interventions. Source: (Waarts et al., 2019)

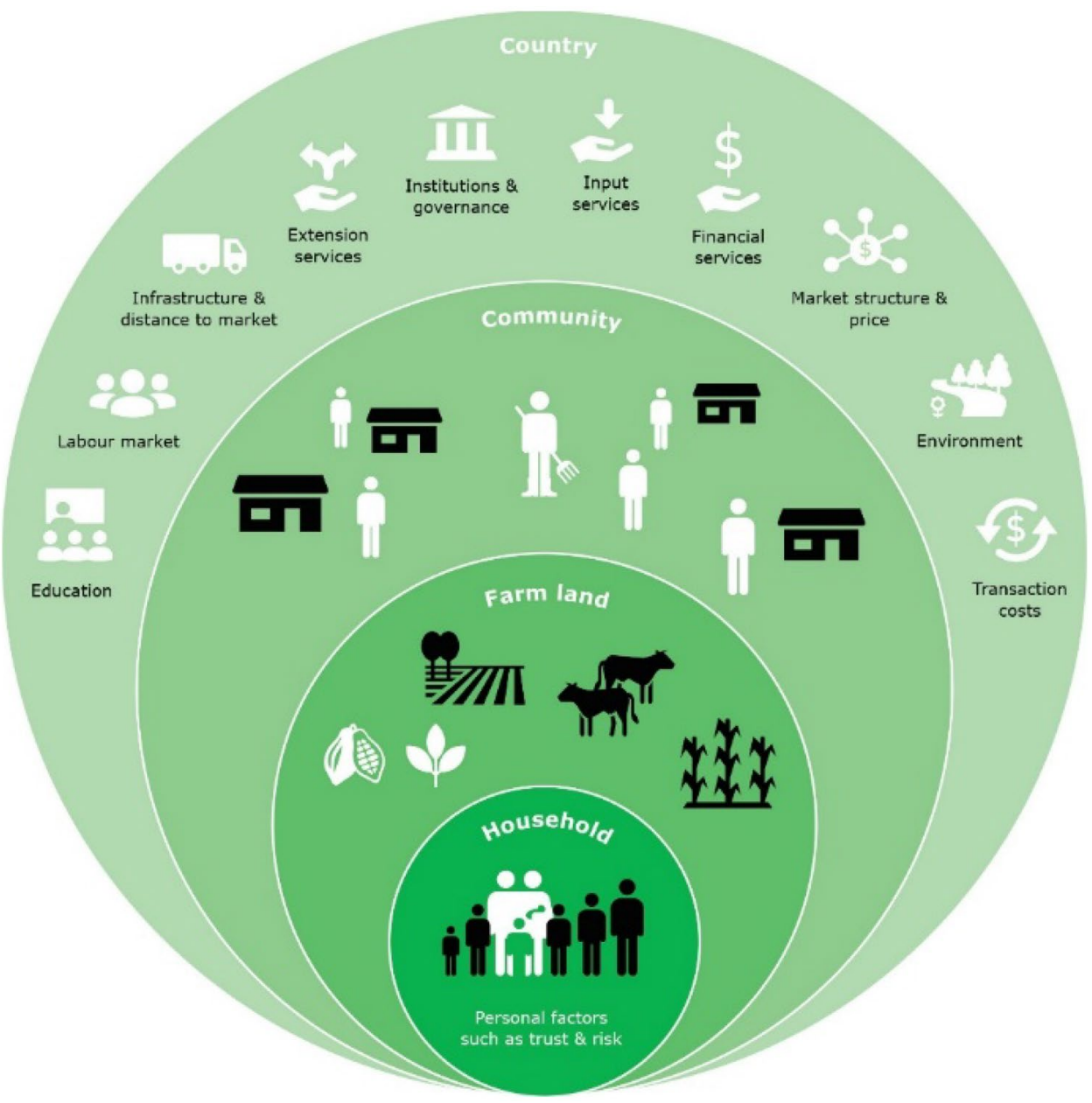

characteristics and farmers' aspirations, the effects of poverty on decision making and the cultural environment. Cultural factors can prevent or enable the uptake of certain interventions. Personal factors, like peer effects, are relevant for interventions, as often assumptions are made about diffusion of the results and outcomes of interventions to neighbours who did not participate in the intervention. It is important for interventions to make explicit such theories of change. In Farmer Field Schools, for example, assumptions about knowledge diffusion have not occurred as anticipated (Waddington et al., 2014).

\subsection{Objective of this paper}

\subsubsection{A living income and food systems approach are used to assess the potential of different types of interventions for smallholder commodity farmers to earn a living income}

This paper sets out to show how the extent to which smallholder commodity farmers are poor and the depth of poverty, for cocoa and tea farmers in Ghana, Ivory Coast and Kenya, and the results of interventions on their household income and poverty levels. After reflecting on root causes of poverty, seen through a food systems and living income lens, we then present a new assessment approach to design and tailor policy interventions, and elaborate policy implications for interventions aiming to achieve a living income. Taking a food systems approach allows us to examine poverty drivers to come to conclusions what intervention pathways would be effective in addressing such drivers.

\subsubsection{We present a new assessment approach to support designing interventions to influence farmer income}

This assessment approach shows the type of data to collect and analyse, to provide evidence that can support intervention design, effective in lifting different types of farmers out of poverty. The approach was developed based on evaluations and studies in the tea, cocoa, coffee and other sectors. When used in conjunction with an assessment of the impacts of different interventions on incomes, this provides 
information on the ability of different interventions to achieve a living income for different groups of farmers. Such evidence enables policymakers and organisations to design more effective and efficient policies and programmes that contribute to achieve living incomes for different types of smallholder commodity farmers.

\section{Methodology}

\subsection{Literature review on impacts of commodity program interventions}

\subsubsection{Review of systematic reviews, overview, and meta studies}

We reviewed literature to find overview studies on the causes of poverty (guided by the food systems approach) and interventions to improve the income of smallholder tree-crop commodity (cocoa, coffee, palm oil and tea) farmers in lower- and middle-income countries. Literature was collected by asking colleagues about relevant systematic and review studies and searching Google Scholar, as not all relevant studies are published in academic journals. The search criteria included any review or overview study that included evidence on the impact of a specific intervention on crop income, household income or poverty status, in which the counterfactual was addressed, for instance through a comparison group. We searched for studies for each specific crop of interest, as well as for studies that covered multiple crops. Five of such studies were included in the analyses. They addressed technical interventions such as training, standards and certification, input supply, access to finance (credit/loans), contract farming and cash transfers. To better describe the learnings, we also sometimes included information from the articles included in such overview studies. With a deliberate attempt not to present biased information. Overview studies of interventions often combine information from different types of sectors and commodities, so they include a wider range of crops and do not present information solely on interventions covering specific commodity sectors. Therefore, the information from the literature presented in this paper cannot always be connected to a specific sector. An overview of the results of the literature review on the impact of interventions on smallholder commodity farmers is contained in Appendix 1.

\subsubsection{Very few studies compare actual income levels of smallholder commodity farmers with the world bank poverty line and/or a living income benchmark as most focus on agricultural productivity increase}

As the living income concept is relatively new, we did not find any studies that assessed the impact of interventions to close the gap between a living income and actual household incomes. Therefore, we searched for impact evaluations that used the World Bank extreme poverty line to report on (changes in) farmer's poverty status instead. However, we found that many studies did not focus on measuring a decrease in poverty levels, but rather focused on assessing the impact on productivity or income increase, or the adoption of good agricultural practices. Systematic reviews did not always focus on the impact of interventions on poverty status either.

\subsubsection{Disaggregation of the impact of interventions by gender or regions was not possible due to scarcity of literature and/or the scarcity of high-quality evaluations}

Even though data on the gender of participants in interventions was often collected, gender-disaggregated results on the effects of interventions were not included in the literature reviewed. Also, the effects of interventions on women's roles and agency in commodity farming were not reported on. Along similar lines, no disaggregated data on interventions in different continents or regions were found, possibly as a result of the low number of high-quality evaluations (see also Bernstein et al., 2019).

\subsubsection{Most impact evaluations do no not include results on poverty levels of households}

Even though we are interested in interventions that deal with the alleviation of smallholder poverty through a food systems perspective, studies that cover those were not found. Therefore, the interventions that were examined are based upon evaluations of interventions that assess the impact on total household incomes. However, many studies focus on commodity incomes rather than total household incomes. Where available, we summarised information from systematic reviews with data on total household incomes, as commodity income increases may not translate in total household income increase. This occurs because of changes in the division of household labour among various income-generating activities. The results presented on the effects on commodity income therefore must be interpreted with caution as they do not incorporate the effects on other sources of income of interventions that may require redistributions of household labour.

\subsection{Primary data analysis of household poverty status}

\subsubsection{Data analysis data of farmer's income levels compared to living income benchmarks}

We analysed primary data from three panel datasets generated to evaluate the impact of interventions on the income 
of smallholder commodity farmers in lower- and middleincome countries:

1. 439 smallholder tea farmers from Kenya: data collected for an impact evaluation study financed and commissioned by KTDA, IDH and Unilever (Waarts et al., 2016). Data are presented for the year 2015.

2. 311 smallholder cocoa farmers from Ghana: data collected for impact evaluation studies financed and commissioned by Solidaridad and UTZ Certified (Waarts et al., 2015). Data are presented for the year 2014.

3. 362 smallholder cocoa farmers from Ivory Coast: data collected for impact evaluation studies financed and commissioned by Solidaridad, UTZ Certified, Cargill, IDH and Nestlé (Ingram et al., 2018). Data are presented for the year 2017.

The farmers in these datasets were seen by programme staff as similar to typical farmers in the cocoa and tea value chain, but our data may have a small bias as half of the sample are programme participants and half of the sample similar farmers to programme participants.

\subsubsection{Calculating the percentage of farmers against the living income and world bank extreme poverty lines}

We used the data from these studies and information from living income and living wage assessments from these countries to calculate the income status with regard to the World Bank poverty line and living income benchmarks to make the results comparable between countries (Anker \& Anker, 2015; Smith \& Sarpong, 2018; Tyszler et al., 2018). And to show the predicted effects of several interventions (e.g. price increases) on farmers' poverty status. For the methodology on the calculation of comparable poverty lines and living income benchmarks, please see Appendix 2.

Information on farm characteristics and farmers' economic status is presented for two groups.

1. Farmers who earn less than the living income benchmark per person per day. In this group, we can distinguish between: i) Farmers who earn less than the World Bank poverty line of USD 1.90 per person per day (2011 PPP) and ii) Farmers who earn between the World Bank poverty line of USD 1.90 per person per day (2011 PPP) and the living income benchmark. This distinction is important to make because many stakeholders work with the World Bank poverty lines, and because this allows for the identification of the poorest and most vulnerable farmers.

2. Farmers who earn the same or more than the living income benchmark per person per day.
Based on this information, we qualitatively assess the potential for different types of commodity farmers to earn a living income, and present an assessment approach that allows, when implemented, to conclude on promising approaches for achieving living incomes for different groups, which are presented and discussed in Sect. 4 on policy implications.

\subsection{Literature review on interventions uncommon in commodity programs}

After the analysis of poverty drivers and evidence on the impact of interventions on smallholder commodity farmer income (presented in Sect. 3), we conducted a literature search again. The focus of this second literature search was to find evidence on policies and interventions that can directly influence farmer incomes, but which is not commonly discussed in literature on smallholder tree-crop commodity farming, nor addressed by most commodity sector programs. Information on the following policies are included: land governance, social assistance programmes, creating employment opportunities, pricing policies and supply management. Again, we focused on including evidence from overview or review studies, added to by specific articles about the three countries for which we present empirical data: Ghana, Ivory Coast and Kenya.

\subsection{Limitations}

\subsubsection{Limitations regarding analyses of environmental drivers, consumer characteristics, and information on interventions not directly influencing household income}

Little data was found on the environmental drivers of a food system connected to poverty outcomes and none was found specifically related to the living income concept. We therefore could not conduct in-depth analyses of all environmental drivers impacting poverty and the potential for farmers to earn a living income. Nor did we assess the effects on the environment of increased income. Data paucity in the literature also meant that we did not present analyses on the effects of (changing) consumer characteristics on the potential for farmers to achieve a living income. As the literature scan provided information about the outcomes of interventions on different commodity sectors and countries, the information presented in this paper cannot be connected to one specific sector or geography. Finally, we focused our literature reviews and analyses on cash income. We did reflect on the value of interventions that do not have a (direct) impact on farmers ability to earn a better cash income but did not include an extensive literature review on such interventions. 
Fig. 4 Percentage of smallholder cocoa and tea farmers above and below the USD 1.90 World Bank poverty line and living income benchmarks. Sources: Ghana: (Waarts et al., 2015) $(N=311)$, Côte d'Ivoire: (Ingram et al., 2018) $(N=362)$, Kenya: (Waarts et al., 2016) $(N=439)$

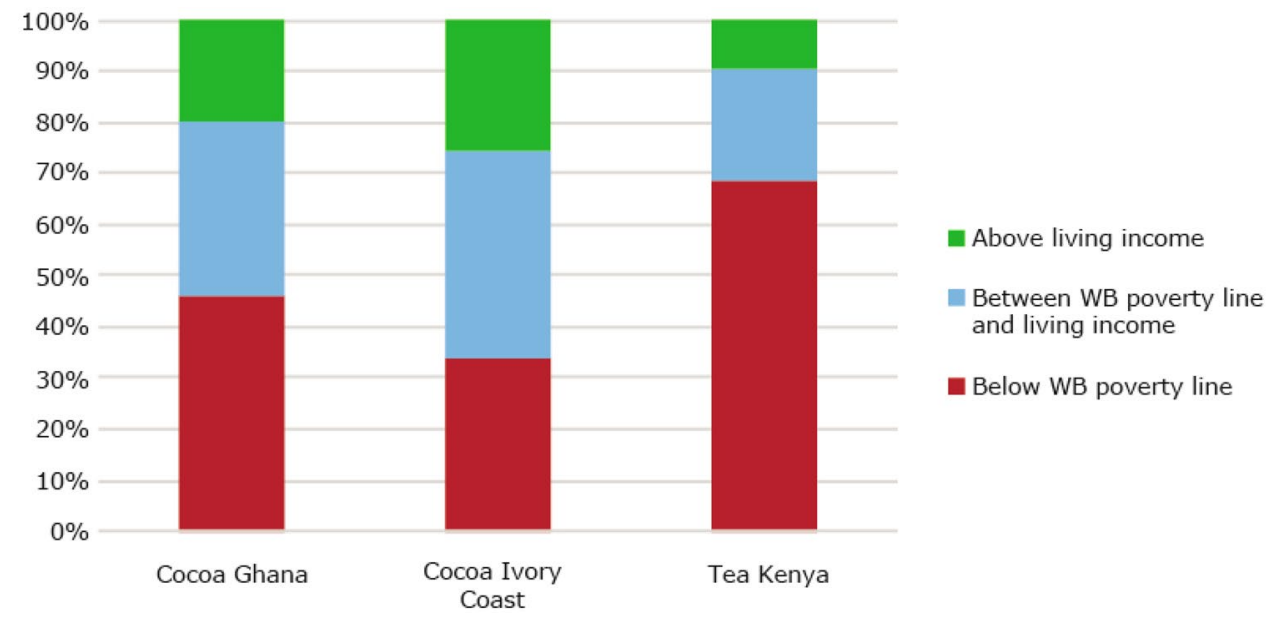

\section{Results}

\subsection{Food system outcome: poverty status of smallholder commodity farmers}

\subsubsection{Most smallholder commodity farmers earn less than the living income benchmark}

Shown in Fig. 4, Findings from the three impact evaluation studies revealed that about $82 \%$ of cocoa farmers in Ghana and Ivory Coast, and tea farmers in Kenya earned less than a living income at the time of study, and more than half (51\%) earn below the World Bank extreme poverty line ${ }^{2}$. In Ghana and Côte d'Ivoire, farmers earn on average about $60 \%$ of the living income benchmark. Tea farmers in Kenya earn on average $47 \%$ of a living income. This situation of widespread poverty in commodity sectors is confirmed in the literature, irrespective of how poverty is defined (WB poverty line or Living income) (Alvarez \& Von Hagen, 2011; Dalberg \& Wageningen University, 2018; Oya et al., 2017; Woodhill et al., 2020). The living income benchmarks for the three countries are: USD 1.32 per person per day for tea farmers in Kenya, USD 2.08 per person per day for cocoa farmers in Ghana, and USD 2.52 per person per day for cocoa farmers in Ivory Coast.

\subsection{Impact of interventions on household income and poverty levels}

\subsubsection{The effect of interventions on total household income is insufficient for many smallholder commodity farmers to earn a living income even if multi-stakeholder food systems approaches have the best chance of success}

Interventions implemented in commodity sectors have between 19 and $90 \%$ effect on crop income, and a 15-32\% effect on household income (Fig. 5). This information is based on several review studies, information from these different studies can be found in Appendix 1. For interventions on productivity enhancement through training and input services, one study found effects between 10 and 50\% (Dalberg \& Wageningen University, 2018). A systematic review on cash transfers to individuals or households, reported that six out of nine studies found a significant impact on poverty measures (Bastagli et al., 2016), but also concludes that in many cases the impact is not big enough to have an effect on aggregate poverty levels, and that long term effects are not clear ${ }^{3}$. A recent review study shows that the total household income increases occuring because of different interventions are not enough for poor smallholder commodity farmers to earn a living income, as they may need income increases of 100-200\% to do so (Dalberg \& Wageningen University, 2018). Another meta evidence review reports that there is 'insufficient evidence to determine trends' for the impact of extension and advisory services and agricultural input subsidies on poverty, and that 'despite evidence, the impact is in doubt' for improved access to financial products (Bernstein et al., 2019). Multistakeholder approaches in which different food system components were addressed have the biggest chance of achieving long-term impact on incomes at scale (Dalberg \& Wageningen University, 2018). However, the impact of many interventions is often not big enough for the poorest farmers to earn a living income.

\footnotetext{
2 The following benchmarks were used for the living income comparisons: (Anker \& Anker, 2015; CIRES, 2018; Smith \& Sarpong, 2018).

${ }^{3}$ Findings range from about 4 percentage points to 8 or 9 percentage points increase total and food expenditure, depending on the measure of poverty.
} 
Fig. 5 Average percentage increase in crop and/or household income of target group compared to comparison group for different types of interventions (in the information on certification, changes in household income were found to be $13 \%$ but were not significant, which is why we did not present this change in the figure). Sources: (Dalberg \& Wageningen University, 2018; Hemming et al., 2018; Oya et al., 2017; Ton et al., 2017; Waddington et al., 2014)

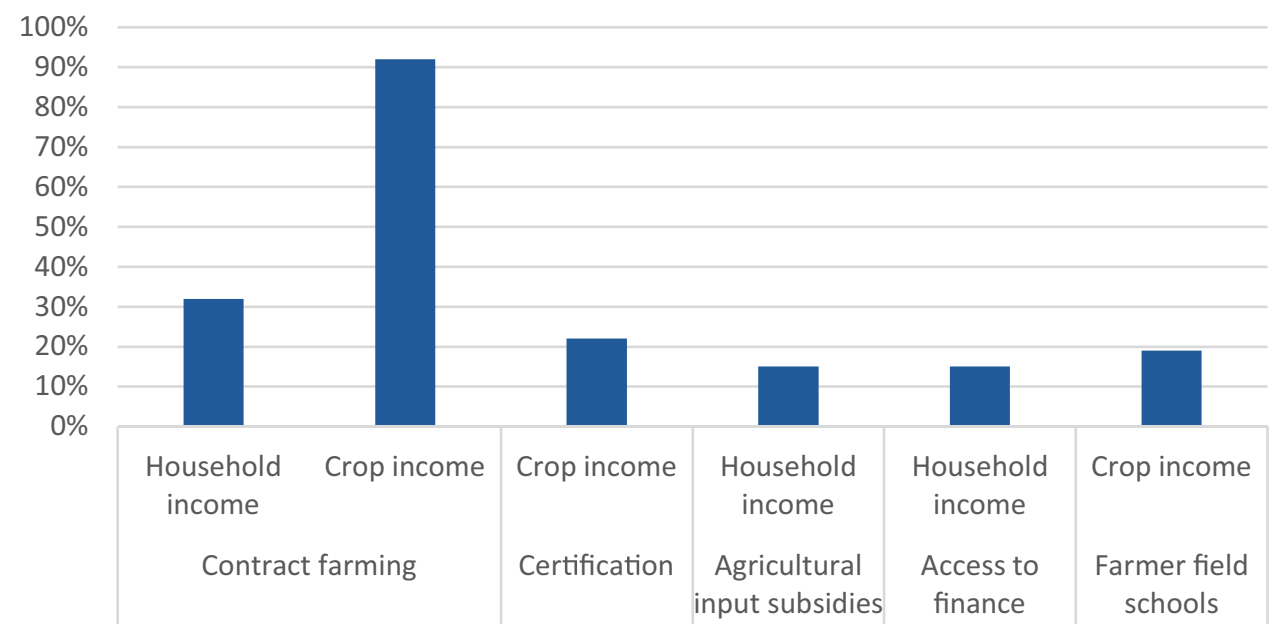

\subsubsection{Positive impacts on income in studies to be interpreted with caution because of study and target group biases}

Various biases in the literature ('survival bias', 'publication bias', 'selection bias' and the fact that not many peer reviewed studies have been conducted) means that the evidence in the literature reviewed most likely overestimates the impact of interventions on income. The reasons for this are that: i) Evidence of projects and programmes that stopped in their early years is generally not collected and/ or published, ii) Farmers included in interventions are not necessarily representative of all farmers in the sector, e.g. the poorest farmers may not participate, iii) Farmers who have dropped out of an intervention are often not included in research after they left the project and iv) If study outcomes are not significant, they are less likely to be published (Ton et al., 2017). Also, the number of academic peer reviewed studies containing evidence on the topic are low.

\subsection{Root causes of poverty levels}

\subsubsection{Socio-economic drivers and the enabling environment}

Farm sizes are often too small to earn a living income, and are likely to decrease due to inheritance structures Small farm sizes can be a key driver of poverty. In Ivory Coast and Kenya, the poorest farmers in the datasets have the smallest farm sizes, 3-4 hectares and about 0.2 hectares on average respectively (Fig. 6); this is also confirmed by another study on the cocoa sector in Ghana and Ivory Coast (van Vliet et al., n.d.). Tea farmers in Kenya have much smaller farm sizes than cocoa farmers in West Africa, but they earn relatively more per hectare than cocoa farmers because they harvest every week to every two weeks instead of twice a year. Land fragmentation is also confirmed by the literature as a driver of poverty (Giller et al., n.d.). studies, minimum farm sizes for 'economically viable' farms are calculated, but we find that such farm sizes are not necessarily minimum farm sizes for earning a living income. One study presents that the minimum economic tea farm unit for smallholder farmers in Kenya is 0.1 ha ( 0.25 acres) (Kavoi et al., 2002). But looking at the datasets, households with such small farm sizes are extremely likely not to earn a living income. In the dataset on cocoa farmers in Ghana, we do not find that poorer farmers generally have smaller farms, but find other important factors influencing poverty levels which are presented below. Small farm size does not have to be an impediment for earning sufficient incomes in all sectors but remains an important factor to consider.

Farm sizes would need to at least double to enable the cocoa and tea farmers, who currently earn below the living income, to earn a living income For farmers to achieve a living income - when all other variables remain constant farm sizes would need to increase significantly, ranging from an increase of four in Ivory Coast to almost eight times in Kenya (see Fig. 7). Interestingly, farm size in Ghana would need to increase more than in Ivory Coast while we saw earlier that farm size is less of a barrier to earning a living income in Ghana than in Ivory Coast. Given that some of the main factors for land fragmentation globally are population growth and inheritance (Demetriou, 2013), and the population of many lower and middle income countries is still growing rapidly ${ }^{4}$, it is unlikely that such increases in farm size can be achieved easily.

\footnotetext{
4 The population of Sub-Saharan Africa, for example, is expected to double by 2050 . Source: https://blogs.worldbank.org/opendata/ worlds-population-will-continue-grow-and-will-reach-nearly-10-billi on-2050
} 
Fig. 6 Mean farm sizes in hectare for different groups of cocoa farmers in Ghana and Ivory Coast and tea farmers in Kenya. Sources: Ghana: (Waarts et al., 2015) $(N=311)$, Côte d'Ivoire: (Ingram et al., 2018) $(N=362)$, Kenya: (Waarts et al., 2016) $(N=439)$

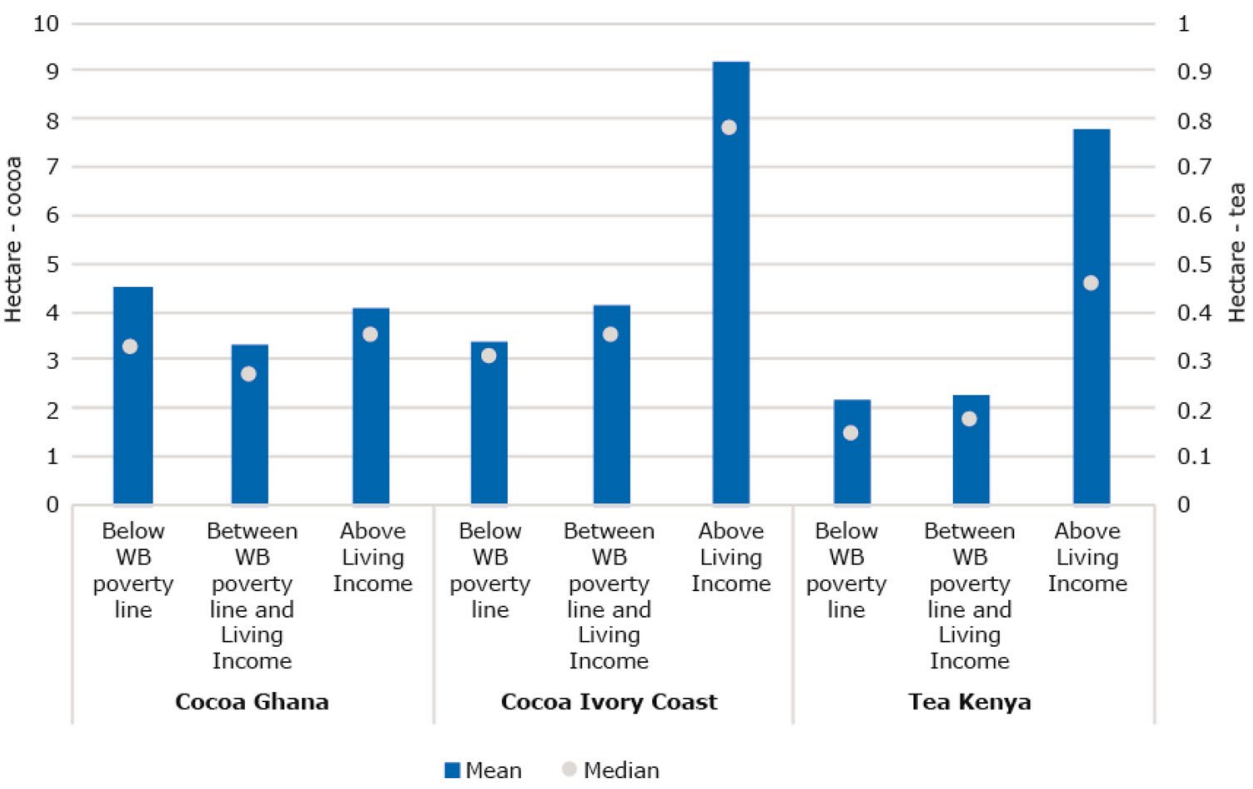

Possibilities for income diversification are limited; farmers are very dependent on cocoa or tea as their main source of income Farmers are very dependent on cocoa and tea as their main source of income as they earn most of their income from the commodity crop (Fig. 8). For example, cocoa farmers in Ghana who earn more than a living income (20\% of all farmers), earn about USD 5000 per year, of which about USD 4000 comes from cocoa (79\%). Cocoa farmers in Ghana who earn less than the World Bank poverty line ( $46 \%$ of all farmers) earn on average about USD 600 per year of which about USD 500 from cocoa (84\%). Differences in dependency on the commodity crop are small between the groups. Income diversification is a challenge for these farmers as opportunities are not available or are not rewarding enough compared to commodity production given

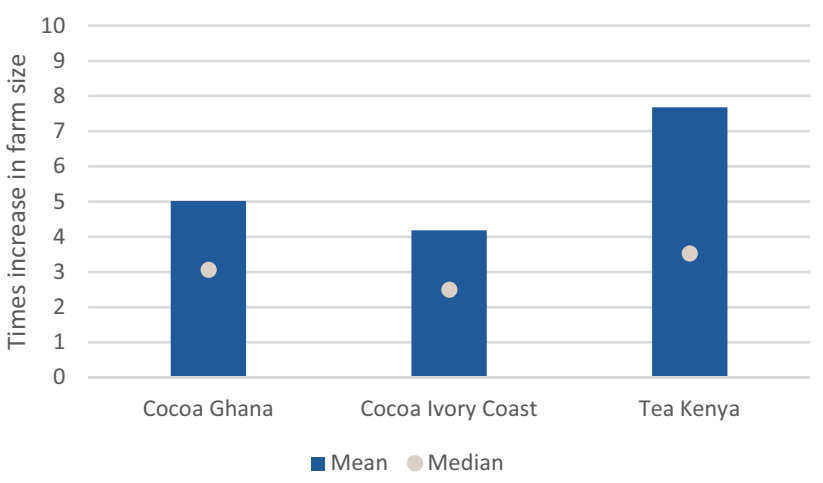

Fig. 7 Increase in current farm sizes needed to close the living income gap for farmers who currently earn less than the living income benchmark. Sources: Ghana: (Waarts et al., 2015) $(N=311)$, Côte d'Ivoire: (Ingram et al., 2018) $(N=362)$, Kenya: (Waarts et al., 2016) $(N=439)$ the current circumstances, human resource assets, and their ability to access investment credit that have affordable (low) interest rates. Access to credit, market linkages and the availability of pro-poor options for conservation, is what drives farmers' incentives and decisions (Shiferaw et al., 2009). At the same time, diversification is often considered as having promising results, also to increase resilience, especially for the poorest farmers (Asfaw et al., 2019).

Commodity market prices are generally volatile and higher prices have not lifted large numbers of farmers out of poverty Global commodity market prices are generally volatile and cannot easily be set by producing countries, and even then hve not resulted in persistently higher incomes (Bymolt et al., 2018; Squicciarini \& Swinnen, 2016). Increasing farm-level buying prices is one of the mechanisms commonly proposed to increase farmer incomes, especially for cocoa, as prices have effectively declined over the past three decades for conventional cocoa (Tröster et al., 2019; Squicciarini \& Swinnen, 2016). Tea prices have decreased since 2013, 'although they remained much higher than the historical average over the previous two decades, both in nominal and real terms' (Chang, 2007). Higher prices, for example paid by some specialty and certified cocoa buyers can contribute to increase farmer incomes but have not yet lifted large numbers of farmers out of poverty (Ingram, 2014; Purcell, 2018; Tony’s Chocolonely, 2020).

Even significant price increases would not achieve living incomes for the poorest tree-crop commodity farmers; relatively richer farmers benefit more because they produce larger volumes An example where governments influence cocoa farm-gate prices is the Living Income Differential established 
Fig. 8 Income earned per household member per year (USD Purchasing Power Parity) (For comparison, the monthly living income line per family was converted to a daily living income per household member). Sources: Ghana: (Waarts et al., 2015) ( $N=311)$, Côte d'Ivoire: (Ingram et al., 2018) $(N=362)$, Kenya: (Waarts et al., 2016) $(N=439)$

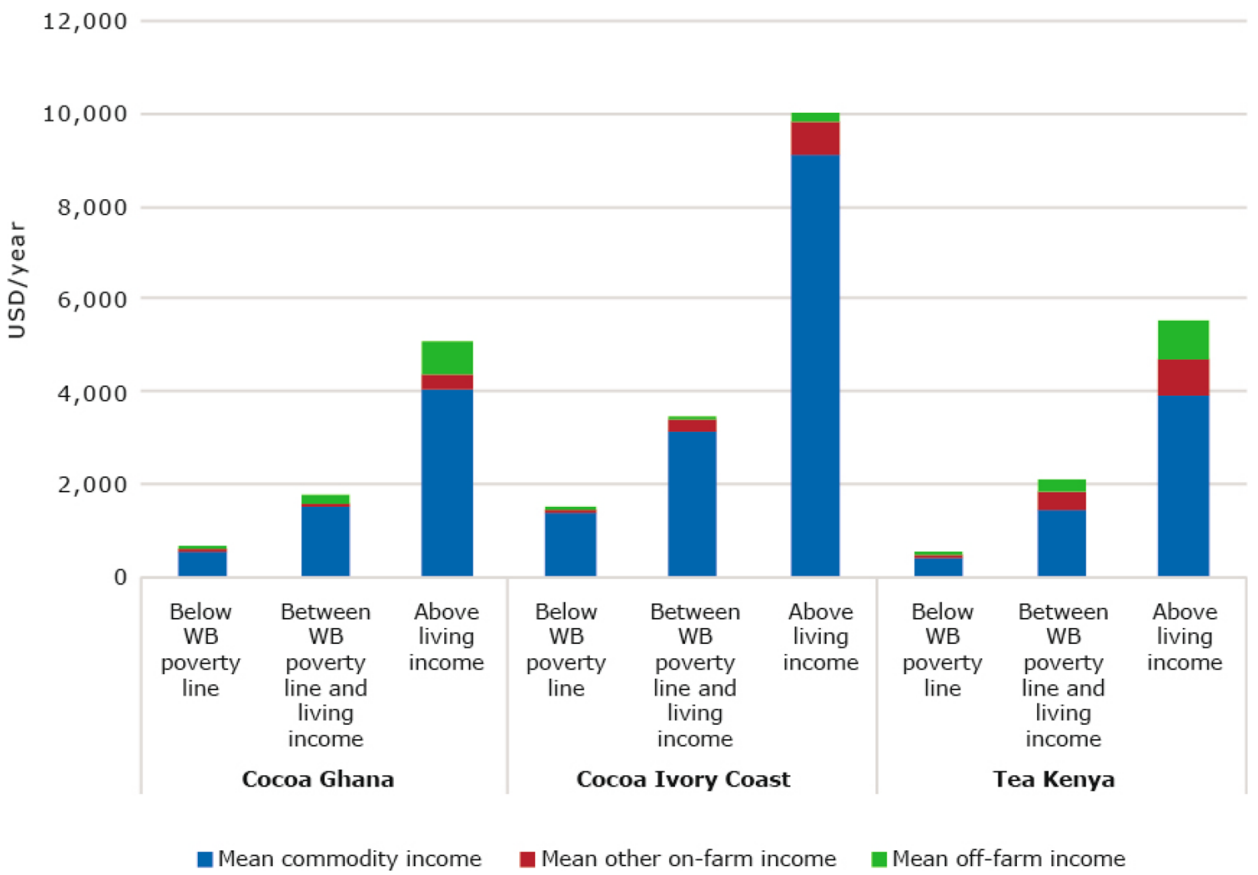

by the governments of Ivory Coast and Ghana to be paid for cocoa from the 2020/2021 season onwards (Angel et al., 2019; Vidzraku, 2018). It amounts to USD 400/Mt cocoa on top of the FOB-price, an increase of $16 \%$ based on a market price of USD 2501/Mt (ICCO, 2020) if it is fully transferred to the farmers. A $16 \%$ price increase would have resulted in about USD 13 additional income per household member per year for the poorest Ghanaian cocoa farmers in our study, who earn less than the living income benchmark as well as less than the World Bank poverty line (see Appendix 3). The minimum Sustainability Differential of USD 70/Mt for cocoa as of July 2022, paid as part of the Rainforest Alliance, 2020 certification programme (Rainforest Alliance, 2020), would have increased incomes by about USD 2.5 per household member per year for the same group of farmers (see Appendix 3), and it would benefit only Rainforest Alliance certified farmers. Even though every additional dollar earned is important for farmers, the benefits of price increases are limited in terms of poverty reduction at scale, as the poorest farmers benefit the least because they produce the lowest volumes. This is also confirmed by a study of cocoa farmers in Ghana and Ivory Coast (van Vliet et al., n.d.): with a 50\% income increase, $30 \%$ of cocoa farmers in Ghana earn above a living income, compared to $20 \%$ without the price increase (Fig. 9).

Price increases may induce oversupply and indirect negative effects on the environment and may lead to companies changing their sourcing strategies. Price increases should therefore be combined with other measures if implemented at scale Price increases generally influence farmers to invest in commodity production, leading to production and supply increase, putting a downward pressure on prices again in the long run if demand for commodities does not increase at the same pace (Waarts et al., 2019). If countries increase prices,
Fig. 9 Scenarios for the impact of price increases on percentage of smallholder cocoa and tea farmers above and below the USD 1.90 World Bank poverty line and living income benchmarks (a $50 \%$ price increase is assumed to lead to $50 \%$ income increase). Sources: Ghana: (Waarts et al., 2015) $(N=311)$, Côte d'Ivoire: (Ingram et al., 2018) $(N=362)$, Kenya: (Waarts et al., 2016) $(N=439)$

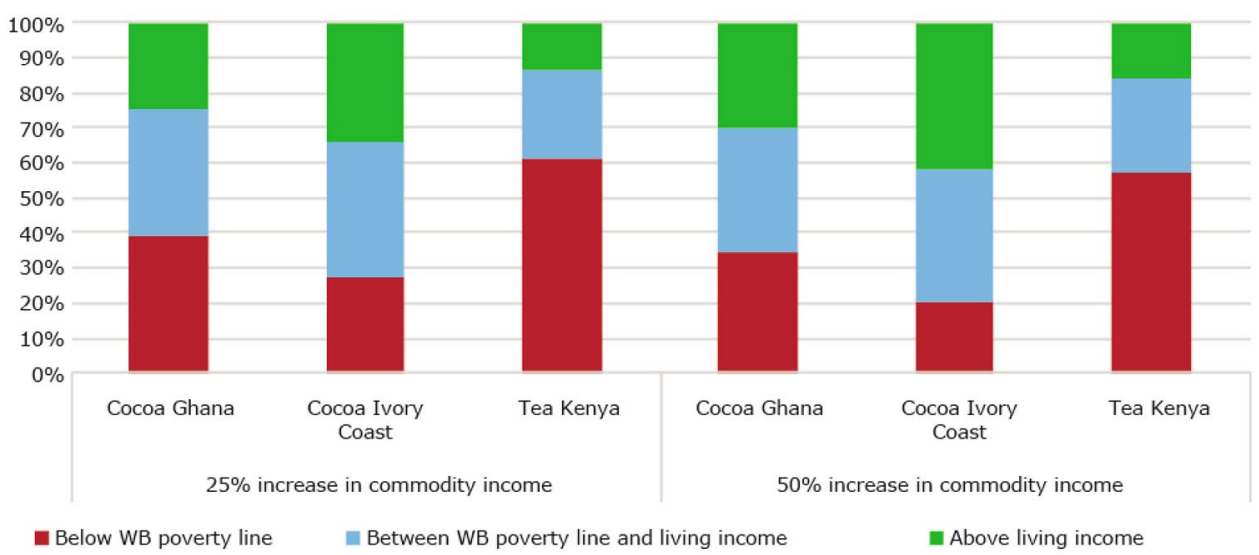


demand for produce from the country could also decrease if buyers decide to buy their produce elsewhere because of lower prices. Incentives that increase cocoa production can enhance deforestation when commodities have elastic demand in the short term (i.e. the price does not decrease when supply increases) such as is the case for many commodities (Abbott et al., 2005; Tothmihaly, 2017). The legal and financial, for example anticompetition and trust law implications of fixing markets prices also need consideration. Additional measures are thus critical if prices increases are to contribute to achieve living incomes and alleviate persistent poverty, ensure no negative effects, externalities, both in country but also tele-coupled impacts globally materialise. This is discussed further in Sect. 4.1.6.

\subsubsection{Food supply system, business services and environmental drivers}

Various factors lead to low adoption rates of good agricultural practices and thus lower incomes Farmers often decide not to adopt new technologies and change their farm management practices and are seen to dis-adopt after initially adopting new practices or technologies. Reasons for low adoption are: i) Failing markets for instance for inputs; ii) Interventions which are not tailored to aspirations, needs and opportunities; iii) Inability to invest time and money, because they do not have the funds and/or a lack of access to affordable credit for instance because of low market prices, and; iv) Investment benefits are not guaranteed leading to financial risk (Bulte et al., 2014; Conley \& Udry, 2010; Greiner et al., 2009; Prokopy et al., 2008; Waarts et al., 2019). Low adoption levels or farming in unfavourable circumstances regarding agro-ecological conditions lead to low yield levels and thus to incomes that are lower than what would be feasible. This is also experienced by cocoa farmers in Ghana and Ivory Coast. Farmers under-invest in implementing farm management practices, which leads to a 'low input-low output' system (Fig. 10). Low yields are attributed to low input use, inadequate weeding and farm maintenance, insufficient pest and disease control, poor shade management, low rates of fertiliser use, and the old age of some cocoa farms (Bymolt et al., 2018; Wessel \& Quist-Wessel, 2015).

Farmer's large yield gaps can be decreased by addressing underlying reasons for low adoption rates of good agricultural practices Productivity levels for cocoa and tea farmers are low compared to what is possible in the study region (Fig. 10). But these productivity levels are especially low for the poorest farmers. A yield gap cannot be easily and quickly closed; there is a good reason why it exists: adoption of new practices can only lead to improved agricultural productivity when conditions and circumstances are right. Farmers are limited by the environmental drivers in the food system (e.g. low soil quality and unpredictable and heavy rains). Mitigating the effects on their livelihoods of these environmental drivers requires the adoption of good agricultural practices, which in turn requires addressing the key reasons for low adoption rates as listed above.

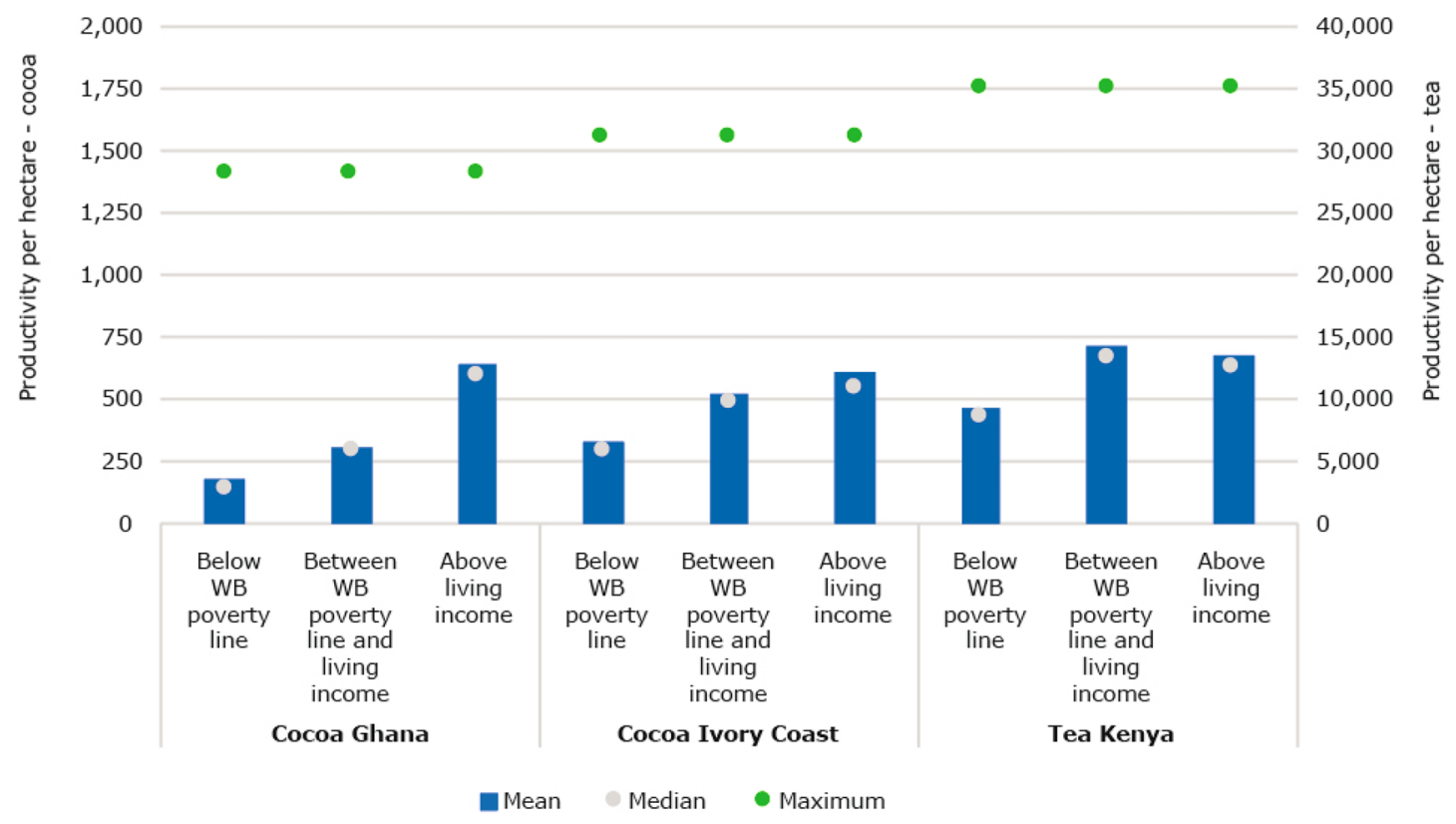

Fig. 10 Productivity per hectare per farmer group and the maximum yield level in the research area confirmed by experts. Sources: Ghana: (Waarts et al., 2015) $(N=311)$, Côte d'Ivoire: (Ingram et al., 2018) $(N=362)$, Kenya: (Waarts et al., 2016) $(N=439)$ 


\subsection{New assessment approach to design and tailor policy interventions}

\subsubsection{Introduction to the new approach}

A new assessment approach to assess the potential of farmers to earn a living income, and design short- and medium-term interventions that address drivers of poverty A first step in intervention design is to assess which smallholder commodity farmers in a certain area and value chain have the potential to earn a living income based on their current conditions, and which do not, and why this is the case. This can be a complex task because multiple factors influence the potential for farmers to earn a living income. To support such a design process, we present an assessment approach which can be used to design short- and mediumterm interventions. This approach was developed based on our empirical research work in commodity sectors ${ }^{45}$ as well as the literature, and inspired by the 'pathways to prosperity' report (Shakhovskoy et al., 2019). It presents the key determinants influencing the ability of farmers to earn a living income and it can be used in different smallholder commodity contexts. It does not provide detailed thresholds for each factor per sector and/or contexts, but it is a tool for policymakers and private sector to understand about the farmers they work with and/or buy from. The assessment approach is elaborated below and shown in Fig. 11a, b.

Six factors need to be assessed, to decide on intervention design focus From our empirical studies, we found six key factors that need to be assessed to support intervention design focus:

1. Commodity profitability per hectare, which includes production volumes, yield per hectare, prices received, and cost of production

2. Farmers' willingness and possibility to invest, including whether there is affordable credit available

3. Farm size

4. Possibility for on-farm diversification, including business activities performed at the homestead/farm.

5. Environmental or climate risk and

6. The number of household members ${ }^{5}$.

Information on these six factors should be analysed in combination with each other for a farmer or group of farmers, to come to conclusions what intervention focus would be most effective. For instance, a farmer may have a very high

\footnotetext{
${ }^{5}$ We consider factor 6 , the number of household members out of scope for interventions but it is an important factor to be taken into account as it affects the money available per household member.
}

profitability per hectare without the chance to improve performance further, but because of small farm size she cannot earn a living income, except when a household member would be employed elsewhere or when a business is established. Based on information on possibility to invest, market aspects and employment prospects, a decision can be made together with the farmer what intervention(s) would work best. Such analyses and discussions can also be conducted for groups of farmers.

Because smallholder commodity farmers are generally quite dependent on income from the commodity, and productivity per hectare and profitability is often low, cocoa profitability is the starting point of the analyses Commodity production is generally a first point of entry for many interventions as they focus for a large part on improving productivity because of large yield gaps, and because the majority is highly depending on income from the commodity. But without the possibility to invest in improving profitability, commodity income cannot increase. Therefore, a second factor to be assessed is the willingness and possibility to make financial investments in farming or other activities. If farmers do not have the means to invest money (through cash, savings, or credit) or are not willing to do so because they need to/ choose to spend their money elsewhere (e.g. funerals, education), it will be hard to increase incomes greatly. Such 'willingness' also includes various contextual and personal factors influencing decision making (see Sect. 1.3).

After assessing farm size and whether and how the farm size hampers income increase, the possibility for on-farm diversification for the generation of cash income is assessed When enough land is available and the farmer is willing and able to invest, but there is no input supply or market demand for alternative crops or supply chains do not function, it will be a challenge to diversify (this also includes relevant contextual factors enabling diversification, see Sect. 4.2). Also, future expectations regarding agro-ecological and climatic conditions are important to be considered to decide whether and how to invest time and money.

When income from farming does not enable farmers to achieve a living income, other ways should be found to strengthen their income and resilience in the short term There is a possibility that farmers cannot increase their income substantially enough for achieving a living income. Because they do not have enough land, money or time to invest, because markets are failing, or because environmental circumstances hamper production. We focused our analyses on cash income as the living income calculations are about the cash income needed for a decent standard of living, but realise that there are farmers who do not have the potential to earn a living income. This consideration needs to be taken into account in the living 
a. Assessment approach for deciding on the focus of interventions (type of food system interventions, and objectives) for different groups of commodity farmers and their households. This assessment approach includes an example of households with the potential for earning a living income, based on their current situation.

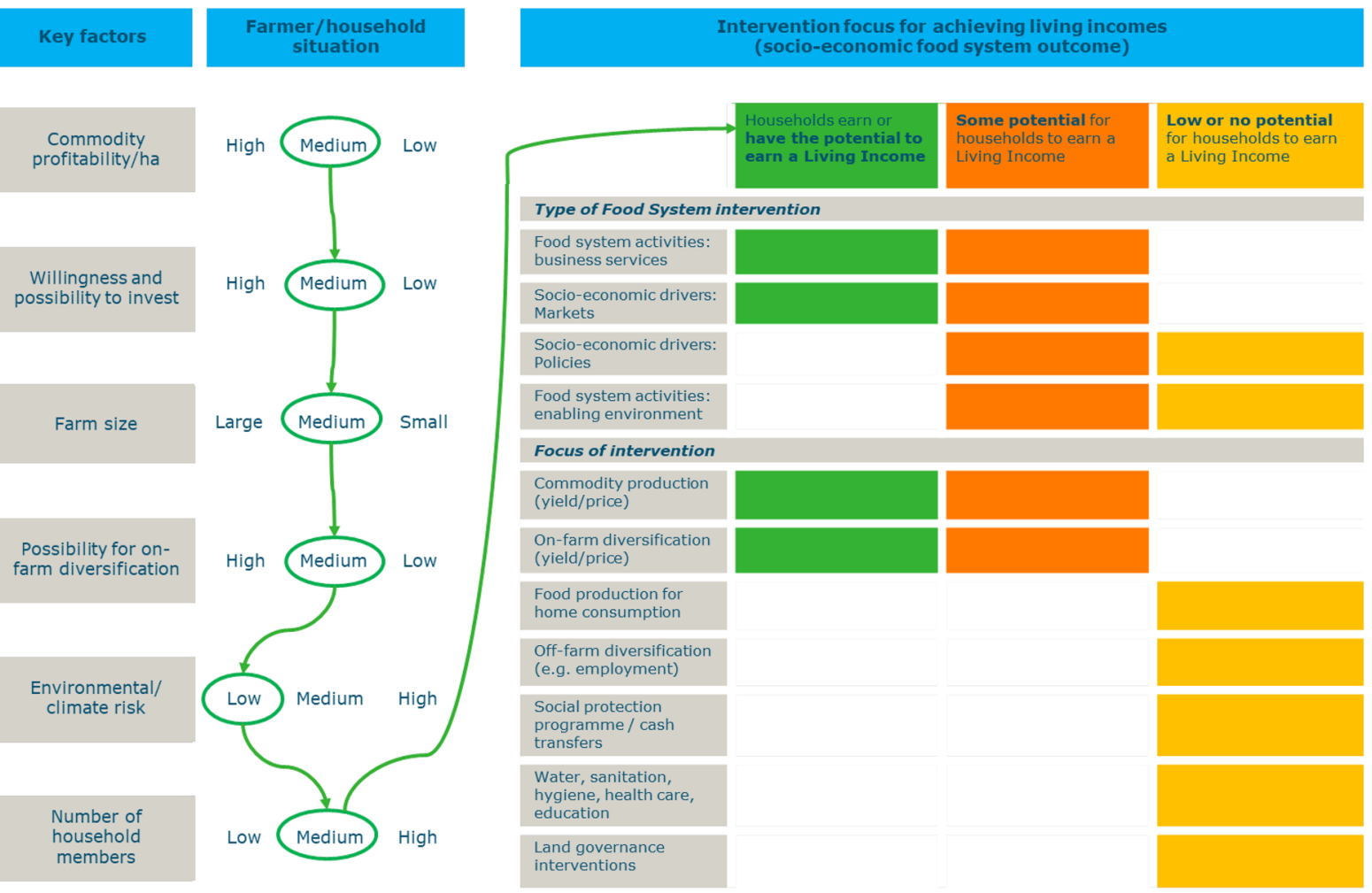

b. Assessment approach for deciding on the focus of interventions (type of food system interventions, and objectives) for different groups of commodity farmers and their households. This assessment approach includes an example of households without the potential for earning a living income, based on their current situation

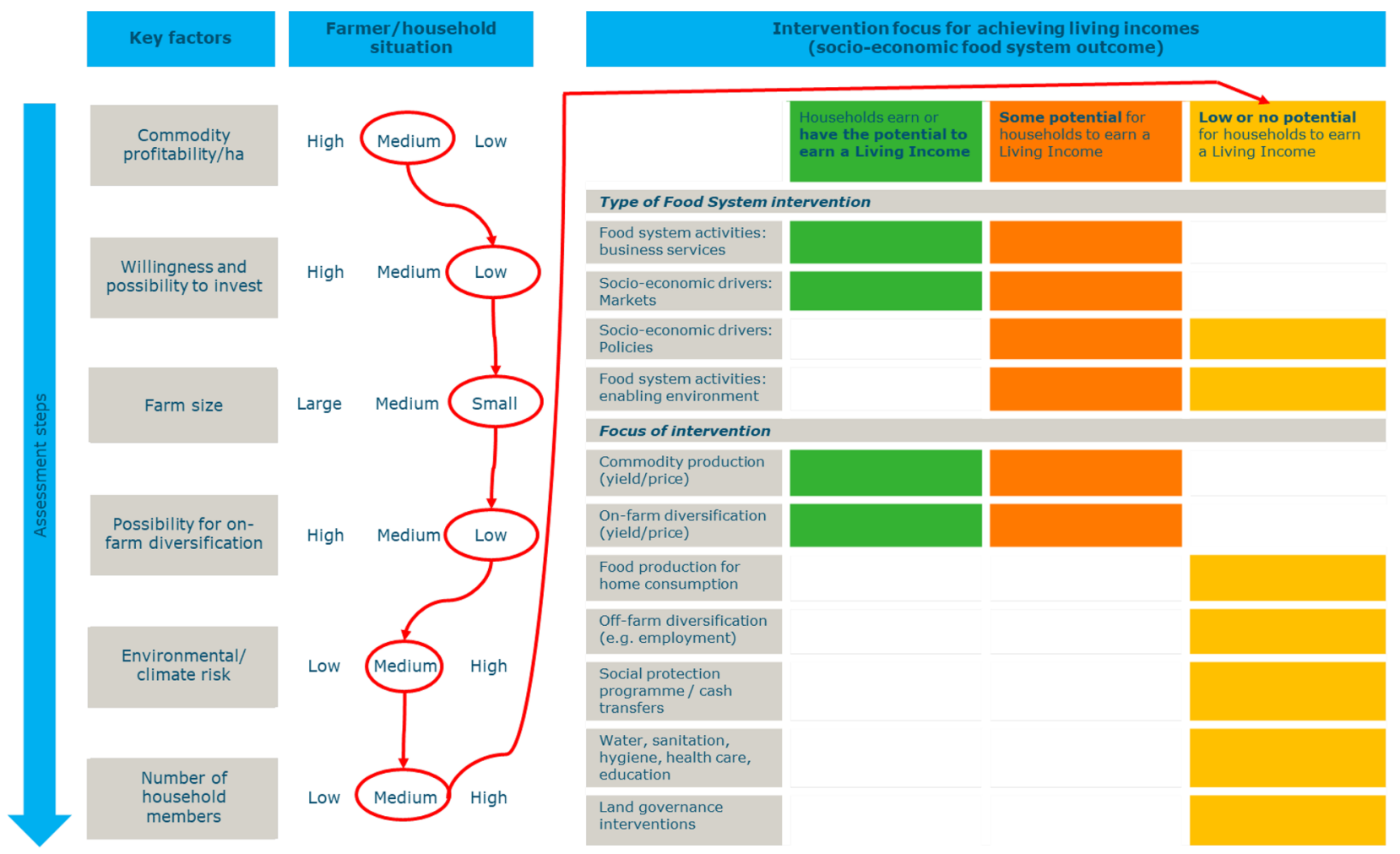


4Fig. 11 a Assessment approach for deciding on the focus of interventions (type of food system interventions, and objectives) for different groups of commodity farmers and their households. This assessment approach includes an example of households with the potential for earning a living income, based on their current situation. b Assessment approach for deciding on the focus of interventions (type of food system interventions, and objectives) for different groups of commodity farmers and their households. This assessment approach includes an example of households without the potential for earning a living income, based on their current situation

income assessment approach as in that case such farmers need different types of support for livelihood improvements. Examples are employment facilitation for direct income effects, helping farmers and their households to become food secure, ensuring children are educated, that health care is accessible as well as safe water and proper sanitation, and by helping people to apply proper hygiene practices. While for all farmers this is important, such support is especially important for farmers without the potential to earn a living income.

When large numbers of households do not have the potential to earn a living income, long term policies around land governance, employment creation and/or cash transfers/ social welfare payments are needed Finally, the assessment approach results may conclude that the economic situation of the large numbers of farmers and their households cannot be improved within their current circumstances (available land, willingness and possibility to invest, possibility for yield improvement and diversification). In that case national, regional or landscape level policies are required that address the structural factors underlying poverty levels such as land fragmentation, employment opportunities and price volatility.

\section{Five possible intervention categories identified as a result of} the living income assessment approach Based on empirical evidence and our experience, the living income assessment approach results in five possible intervention categories built on the potential for farmers to earn a living income and types of food system interventions to do so (see also Fig. 11a, b):

1. Farmers who earn a living income or have the potential to do so: Interventions to focus on improving income from commodity production. This may include yield or price improvements, cost reductions or a combination.

2. Farmers who earn a living income or have the potential to do so. Interventions to focus on improving income from on-farm diversification, possibly in combination with improving commodity income. This may include yield or price improvements, cost reductions or a combination.

3. Farmers who have some potential for earning a living income: Interventions to focus on improving income from commodity production. This may include yield or price improvements, cost reductions or a combination.

4. Farmers who have some potential for earning a living income: Interventions to focus on improving income from on-farm diversification, possibly in combination with improving commodity income. This may include yield or price improvements, cost reductions or a combination.

5. Farmers with a low or no potential to earn a living income: interventions to focus on the following support, depending on needs and possibilities:

(a) Off-farm diversification, such as employment

(b) Food production for home consumption, to improve food and nutrition security

(c) Water, sanitation, hygiene, healthcare and education

(d) Social protection programmes.

(e) Land governance interventions when many farmers have too small farm sizes hampering them to earn a living income.

\subsubsection{Assessment approach results based on empirical data presented earlier}

A large proportion of households in our data are estimated to have a low potential to earn a living income. They need different support than farmers who have the potential for earning a living income Interventions aimed at commodity profitability improvement are suitable for farmers who have the potential to earn a living income based on their current conditions. For instance, because their profitability can be improved, they have medium to high willingness and possibility to invest, they have enough land, and environmental/ climate risk is low. In a situation where such farmers also have the possibility to earn additional income though diversification, such farmers can also be supported in on-farm diversification, depending on farmers' aspirations as well as the expected benefits of both options. For more information on how to implement such support activities with these farmers, please see Sect. 4.2. In Ghana, Ivory Coast and Kenya, 20\%, 26\% and $10 \%$ of the farmers in our data earn a living income respectively. We cannot calculate the exact proportion of farmers who have the potential to earn a living income, but based upon our data, the literature and experience, we conclude that a large proportion of households does not have the potential to earn a living income without policies that address the structural factors underlying poverty such as employment, land fragmentation, price volatility and social protection programs. 


\subsubsection{Connecting living income assessment approach results to policy implications for intervention design}

The food systems approach is used as a lens to look at interventions that may contribute to achieving living incomes, focusing on interventions supporting the most vulnerable farmers In designing interventions aiming to lift smallholder commodity farmers out of poverty, it is important to take a food systems approach for the interventions to be effective and not a commodity production approach. Therefore, we use the food systems components to discuss evidence on different interventions and how they could contribute to achieve a living income based on the literature in Sect. 4. In the living income assessment approach, we start the analyses with commodity profitability as commodity farmers largely depend on commodities for their income, and governments, companies and NGOs also often have a commodity focus. The five intervention categories defined as a result of our living income assessment approach are integrated in the discussion on policy implications in Sect. 4. This integration is also depicted in Fig. $11 \mathrm{a}, \mathrm{b}^{6}$. We start the discussion on the interventions with interventions addressing socio-economic drivers and the enabling environment (Fig. 2). This because a large proportion of farmers in our datasets have a low or no potential to earn a living income based on their current conditions and are therefore in need of such interventions. We cannot recommend which intervention would be best suited, and which interventions should be prioritised, as the contexts in which smallholder tree-crop commodity farmers operate differ widely between countries and within countries. Therefore, based on the results of the living income assessment approach, organisations together with farmers, households and communities should decide on what interventions are most suited.

\section{Policy and practical implications of interventions to achieve a living income}

\subsection{Interventions addressing socio-economic drivers and the enabling environment}

\subsection{1 'One health' interventions}

'One health' type interventions in for example water, sanitation, hygiene, health care, food and nutritional security

\footnotetext{
${ }^{6}$ We do not include an analysis on how to address the number of household members, as we see that as beyond the scope of action. However, it remains an important factor to take into account as the number of household members has a significant influence on the capability of a household to earn a living income. The reason for this is that to earn a living income, the living income benchmark needs to be met regarding household income per household member per day. With large households, a high income needs to be earned to meet the living income benchmark (see also Sect. 1.2).
}

(Arsyad et al., 2019; Walton et al., 2020) combined with education can be important in alleviating poverty. This is especially in cases where farmers do not have the potential in the short and medium term to earn a living income from their main cash crop. Interventions for these farmers could focus supporting farmers and their communities to improve their living conditions and the environment. As we focus in this paper on the living income concept, and therefore on interventions with a direct sphere of influence on increasing incomes, further details of such interventions are out of scope of this paper.

\subsubsection{Addressing land fragmentation: policies aimed at formalisation and privatisation of land tenure}

Policies on land governance and job creation enable people to improve their situation and/or move out of self-employed farming. If some farmers 'move out', this may enable remaining farmers to earn a living income Land fragmentation is a challenge in Sub-Saharan Africa, with 'a vast majority of farms far less than 1 hectare' and there are expectations that farm sizes will further decrease due to the increasing population in connection with inheritance structures (Giller et al., n.d.). To prevent increases in poverty due to land fragmentation, policies are needed on land governance and employment creation that support people to improve their situation with farming or move out of self-employed farming into other activities. People finding employment elsewhere may give remaining farmers the opportunity to work on a profitable farm that enables them to earn a living income. Such a process should be properly implemented to avoid human rights violations. To achieve shifts of labour to other sectors it is important that the enabling environment is correctly set up for this. Policies to be analysed for improvement are: tenure and land use planning (e.g. on farm ownership and minimum farm size) and inheritance structures and policies.

Different land tenure systems determine how access to and control over land is governed and are therefore of key importance for land use planning Land tenure systems in sub-Saharan Africa can generally be divided into three main categories: private land, public (state-owned) land and community land (customary tenure) ${ }^{7}$. Both private land and public land are governed by statutory law, as opposed to customary law where land is often communally held and transferred by a 'traditional' law of succession rather than formal transfer of title (Atwood, 1990) ${ }^{8}$. Different tenure

\footnotetext{
7 In addition, there are cases of common land or open access tenure where there is no control on access to resources.

${ }^{8}$ It is dangerous to generalise about African land tenure systems, as they are diverse, dynamic, shaped by laws, policies, contexts (Atwood, 1990).
} 
systems often co-exist and in some cases overlap. Many countries, including Kenya, Ghana and Côte d'Ivoire, have a plural tenure system including forms of private, public, and customary land tenure (Putzel et al., 2015) ${ }^{9}$.

In a response to drastic political and socio-economic changes that have impacted land use and increasing pressure on land in Sub-Saharan Africa, many countries have initiated land reforms in the past twenty years Policy discussions since the 1990s have reflected conflicting interests and different visions of legal reform around land. These can broadly be divided into three categories: i) the agenda centred on formalisation, registration and promotion of private property rights; ii) efforts to institutionalise smallholder user rights and iii) reinforcing community land rights (Boone, 2019). In line with the first agenda, also advocated by the World Bank, many African countries have adopted land law reforms that aim at individual registration and land titling, which brings farmers who were previously operating under customary law under a private/modern tenure system. Examples are Kenya's land reform in 2012 and Côte d'Ivoire in 1998 and 2015. The objective of privatising farmland has been to integrate smallholders into the market economy and to create opportunities for investment, modernisation and upscaling.

The formalisation of land rights may negatively affect vulnerable groups Land registration is often advocated as a pro-poor empowerment strategy, and 'some see registration and titling as a way to protect smallholders' rights of access to land' (Boone, 2019). However, the formalisation of land rights can generate a number of tensions and tradeoffs. For example, it can expose poor and vulnerable groups to adverse market effects. Markets potentially expose poor farmers and vulnerable groups to high risks of dispossession, as the process of individualisation and formalisation of land titling does not recognise all existing forms of land use and land ownership (Chang, 2007). Formalisation often materialises as top-down restructuring and involves risks including elite capture (Putzel et al., 2015). The process of formalisation may actually solidify practices that negatively affect vulnerable groups, including women, youth, ethnic minorities or land-users that do not own land (AFD Land Tenure \& Development Technical Committee, 2015; Notess et al., 2020). In addition, changes that erode communal structures enhance the economic autonomy of individuals vis-à-vis extended families, community leaders, or the community at

\footnotetext{
9 This is reflective of the prevalence of dual legal systems: as statutory land laws were introduced by colonial authorities, local communities often continued to hold land under 'traditional' customary systems. But even in states that were not formally colonised or occupied, land formalisation has taken place well before World War II (Putzel et al., 2015).
}

large, which creates individual opportunities but might also have larger socially-disruptive effects (Boone, 2019).

\subsubsection{Addressing land governance: fragmentation, land rights protection, and communal approaches to agricultural production}

As a response to the market-led dispossession of smallholder African farmers, an option is to secure smallholder farmers land rights Advocates of this approach argue that user-rights securitisation would protect the poor from arbitrary dispossession by government, powerful elites, and other so-called 'land-grabbers' (Stein \& Cunningham, 2017). Programmes have also focused on reducing disruptive land conflicts and strengthening the position of women. Registration that aims at securing smallholder user-rights often involve local-level land administration and governance institutions empowering rural communities and their members to govern their own assets locally. A question is how these regimes are sustained over time in the face of changes such as growth of extended families, on-going socio-economic differentiation or adverse shifts in national and international regulatory contexts for smallholder agriculture (Boone, 2019). The importance of tenure security for smallholder farmers and other vulnerable groups of land-users is now widely acknowledged by scholars, policymakers and practitioners.

...or strengthening of communal land rights Rather than individual titling, this would mean the legal recognition of local communities' collective right to own customary tenured lands, with guaranteed full legal protection as private land-owners. Potential tension or trade-offs of such schemes are the extent to which they compromise (national) democratic institutions and solidify the power of local elites. In addition, formalising community ownership has the potential effect of 'hardening' group identities and artificially creating group boundaries, by formalising who belongs or does not belong to a particular group or community (Boone, 2019; Putzel et al., 2015). In a recent example, six communities in Lofa County, Liberia, have been certified as land-owning communities by the Liberia Land Authority in 2020 (FPA, 2020). This means the communities now govern and manage their land collectively, according to their own by-laws administered by a representative local body. It will be interesting to learn whether the expected benefits of this process, such as forest protection and the improvement of livelihoods (IDH, n.d.), indeed materialise on a landscape scale.

Alternative land use governance mechanisms such as 'block farming' could lead to better incomes, though there is a lack of evidence on their impact on commodity farmer incomes A mechanism that may increase farmer incomes through efficient labour division and cost-effective service 
delivery is 'block farming', which has been implemented in commodity sectors in the past two decades. Collaboration between farmers and with the first buyer can create economies of scale in both production and service delivery. Various forms of block farming exist. In a first model, the processor owns or has full control of the land (e.g. titles), farm management is done collectively and farmers are paid for what they produce (Ugwu, 2020) or are paid wages while also sharing in the enterprise's risks and rewards as part-owners (PEF, 2016). A second model is one where a group of farmers owns the land title and works together to optimise costs (Kimbugwe, 2020). A third model is one in which individual farmers own land titles and manage their farms individually while collaborating with other farmers (Pantoja et al., 2019). Even though we find positive information on such mechanisms' impact on income, we did not find evidence based on academic research standards that (all participating) farmer incomes improved and whether they improved enough for most farmers to be lifted out of poverty (Department of Agrarian Reform, 2019; IFPRI Ghana, n.d.; Matenga, 2017; Nicavera, 2018; Pantoja et al., 2019).

Potential unintended negative effects of 'block farming' Block farming is often described as a mutually beneficial relationship between processing companies and smallholder farmers - but there are some trade-offs, such as a possible refiguring of social relations (Matenga, 2017) and gender imbalance. There can also be longer-term risks or tensions associated with the loss of control/ownership over land. A well-implemented block farming model programme has the potential to provide a sustainable supply of raw materials to the processor while at the same time improve income and livelihoods for smallholders. For block farming models to work, land titling is seen as crucial, but defining the bounds of tenure and individual/communal ownership can be a challenge (Kimbugwe, 2020).

There is no 'one size fits all' solution: each approach to land governance has potential tensions and trade-offs What is an appropriate sustainable and rights-based solution to land fragmentation is a highly contextual question. This requires attention to the existing land use and land ownership practices, power asymmetries and inequalities based on gender, lineage, age, group membership that are already embedded in existing land ownership/inheritance structures and (informal) land use practices. This also requires attention to the social undesirability of selling of or leasing out inherited land. Also, the expected impacts of such solutions should be assessed. It is equally important to recognise the dynamic aspirations of all the people in a certain area including the poorest, the diversity among them, and different options for livelihood diversification, as presented in Fig. 8. Also, climate change forecasts and demographic trends such as urbanisation, and forest and biodiversity protection targets should be integrated in creating new land use plans.

\subsubsection{Alternative employment opportunities}

Alternative employment opportunities need to provide better options than self-employed farming for people who decide to earn an income other than from commodity crops. But earning a living wage is generally not guaranteed in many sectors If alternative employment opportunities are not considered better compared to selfemployed farming, people might not be willing to switch, even when switching to other activities may allow them to obtain additional income from renting out their land. There is no guarantee that switching to other activities will lead to earning a living income. Living wage benchmarks are generally much higher than minimum wages and prevailing wages (Global living wage coalition, 2020). For instance, the living wage benchmark for the banana sector in Ghana finds that, on average, workers are paid $74 \%$ of the living wage estimate (Smith \& Sarpong, 2018), whereas households engaged in self-employed farming in the cocoa sector on average only earn $48 \%$ of the living income benchmark (Smith et al., 2017). This indicates that in Ghana cocoa farmers might be better off financially when they switch to wage labour in the banana sector. Also, though, it indicates that such a switch does not guarantee them to earn a decent income.

Creating new and decent employment opportunities has proven to be difficult Regardless of the relatively high economic growth that has been experienced by African countries, growth in decent employment was very low (Yaïche, 2019). This is partly a result of the unsuccessfulness of structural transformation, characterised by the limited contribution of the manufacturing sector to economic growth (Yaïche, 2019). Many projects with the aim of creating new job opportunities have focused on small firms. Although small firms may grow faster than large firms after surviving the first couple of years, when survival rates are taken into account (about half of the firms no longer exists after 3 years), expected job growth for large and small firms does not significantly differ. Additionally, wages are much higher in larger firms (Page \& Söderbom, 2015). An example from the tea sector in Malawi shows that thanks to a collaboration since 2015 between plantations, unions, tea buyers and the government, the gap to a living wage was decreased. But living wages have not been achieved yet because of inflation eroding the value of wage increases and the exchange rate between the US Dollar and the Malawi Kwacha amongst others (Chiwaula et al., 2020). 
Improving education and infrastructure could benefit the creation of off-farm employment opportunities and agricultural production To stimulate labour transfers out of self-employed farming, policy makers may wish to consider relevant enablers and barriers. Investments in employment creation should not focus solely on supporting small firms, but should i) focus on removing the constraints for firms to grow, ii) identify firms with a high potential to survive, and iii) support firms not only in terms of finance but also capacities (Page \& Söderbom, 2015). Firms of all sizes report that infrastructure deficiencies (electricity and transportation) are the most important barriers to growth (Page \& Söderbom, 2015), which would also be key leverage points for the adoption of better agricultural practices and increasing agricultural productivity (Page \& Shimeles, 2015). Access to some public and private assets (including education) are generally advocated as enablers to increase non-farm activities of rural households (mainly through self-employment), whereas being credit constrained or experiencing poor infrastructure or poor locations may hinder non-farm self-employment (Dedehouanou et al., 2018). A focus on private sector development in agro-processing, manufacturing and tradeable services, with a focus on the export sector, is needed to create more and better jobs (Page \& Shimeles, 2015).

\subsubsection{Social assistance programmes and cash transfers}

Cash transfers and basic income interventions are tested and proposed to decrease poverty Currently, social protection systems are weak in Sub-Saharan Africa and, if they exist, they 'tend to benefit mostly formal workers' (Molina $\&$ Ortiz-Juarez, 2020) and thus generally do not benefit smallholder farmers and their households. Social protection systems, and specifically social assistance programmes including cash transfers, could improve the income of those poor smallholder commodity farmers in Sub-Saharan Africa who do not have the potential to improve their income. Social assistance systems are currently specifically called for because the Covid-19 outbreak creates 'devastating costs for the livelihoods of less advantaged people' (Molina \& Ortiz-Juarez, 2020). Cash transfers can be unconditional or can contain behavioural conditions for receiving the payment but often are implemented for a short duration. More recently Universal Basic Income schemes ${ }^{10}$ were started or are prepared, and a Universal Ultra Basic income has been proposed (Banerjee \& Duflo, 2019; Molina \& Ortiz-Juarez, 2020). The payment of Temporary Basic Income (TBI) has been proposed as a response to the effects of Covid-19.

\footnotetext{
${ }_{10}$ Universal Basic Income (UBI) or Universal Ultra Basic Income
} (UUBI).
There can be differences between the interventions in: who is targeted (all or only the poor? Only certain age groups?), who in a household receives the income (each individual or one person for the entire household?), and the height of the payments.

There are different ways in calculating the height of the payments The ILO indicates that the benefit level of the Universal Basic Income should at least ensure a basic standard of living ${ }^{11}$ for those who do not have another source of income: 'If benefit levels remain far below the poverty line, the expected effects of a UBI on the reduction of poverty and inequality, empowerment and economic freedom remain an unfulfilled promise' (Ortiz et al., 2018). However, according to the UBI proposals and experiments presented in a 2018 report, many benefit levels are below the national poverty line (Ortiz et al., 2018). For the TBI, three methods to decide on the payments are presented: 'top-ups on existing average incomes in each country up to a vulnerability threshold; lump-sum transfers that are sensitive to cross-country differences in the median standard of living; lump-sum transfers that are uniform regardless of the country where people live' (Molina \& Ortiz-Juarez, 2020). The cost of implementing the TBI is based on people earning at least the national poverty line. The UUBI are proposed to be a 'regular cash transfer that amounts to enough for basic survival' (Banerjee \& Duflo, 2019; Duflo \& Banerjee, 2020).

Cash transfers increase the incomes and resilience of poor and vulnerable households. The amounts paid may not guarantee a basic or decent standard of living, but large multiplier effects may occur The available evidence around cash transfers shows that there is sufficient evidence to conclude on a beneficial impact on poverty reduction (Bernstein et al., 2019) but also that there is a great variation in the impacts found (Banerjee et al., 2019; Bastagli et al., 2016). It also appears that in many cases the impact is not big enough to have a direct effect on aggregate poverty levels (Bastagli et al., 2016). Furthermore, with large-scale implementation of money transfers for a longer period of time, the welfare gains depend on where the money comes from to fund the mechanism (Banerjee et al., 2019; Bastagli et al., 2016). One study estimates a large multiplier effect of a long-term cash transfer programme in Kenya (Egger et al., 2019).

Possible unintended effects and trade-offs of cash transfers and basic income to be taken into account There are various unintended negative effects that could materialise when cash transfers or basic income measures are implemented. Such

\footnotetext{
11 They assume the National poverty line ensures such a basic standard of living.
} 
payments should not replace existing social security systems without covering 'life-cycle contingencies' which are generally covered by such systems (Ortiz et al., 2018), otherwise the beneficiaries may be worse off in the long run. Additional income may furthermore result in the increase of prices of perishable/protein rich food, which would be a challenge for the poorest households as they spend a large proportion of their income on food (Molina \& Ortiz-Juarez, 2020). Such price increases could thus result in food insecurity (Kandpal, 2019), but price inflation may also be minimal (Egger et al., 2019). It also matters whom the payments are made to within a household. If payments are made to individuals regardless of household composition, this avoids 'within-household discrimination that could be particularly harmful for women's empowerment and control of economic resources' (Molina \& Ortiz-Juarez, 2020). The ability of a country to afford direct cash payments, particularly when the commodity is a major source of foreign exchange and sold at low prices, has implications for the need to reconsider and model the impacts of national and global commodity market price changes.

\subsubsection{Pricing policies and supply management to achieve stable and remunerative prices in the long run}

Supply management could be used to address market failure, and stabilise prices, avoid oversupply and mitigate negative environmental impacts Stable and remunerative commodity prices are vital to productivity growth, raise farmer incomes and enable the agricultural sector to be an engine of economic development. Commodity price increases work in some niche market segments to increase incomes (Tony's Chocolonely, 2020) but evidence is lacking that they improve profits for large numbers of farmers at sector level. This raises the discussion about the role of measures that seek to match production with demand. Because higher prices at scale could induce farmers to produce more, they may create a downward pressure on prices (Squicciarini \& Swinnen, 2016). One of the solutions for increasing commodity prices without inducing negative effects is to establish a system of internationally agreed supply management to match production with market demand. Production and trade could be managed through buffer stocks, national quotas, measures to limit production to national quotas and to discourage free riding by countries. Such systems could generate funds to pay payments to farmers in a specified area for environmental protection or diversification, taking a conservation and landscape approach to supply management (Koning \& Jongeneel, 2008). Such systems avoid the current effects of largely cocoa futures market price is generally used to set national benchmark conventional cocoa prices (Oomes et al., 2016), where there is little opportunity for farmers and processors of conventional cocoa to determine prices, other than in the niche cocoa sector, such as the speciality, fine flavour and some certified chocolate markets (Bonjean \& Brun,
2016; Squicciarini \& Swinnen, 2016). The international commodity agreements for coffee, cocoa and sugar are examples of such supply management measures, but they collapsed in the 1980s because of opposition from companies and organisations in consuming countries (Koning \& Jongeneel, 2008). The International Coffee Agreement (1962-1989) retained export quotas and successfully moderated the coffee price fall until 1989 (Akiyama \& Varangis, 1990). In response to the recent cocoa price fall, such a system is explicitly mentioned in the declaration of the 2018 conference of the International Cocoa Organisation (ICCO, 2018). Prerequisites for such systems to work are that there are: relatively few producing countries, no other product that can substitute the commodity, leadership responsibility lying with producing countries, farmers and their organisations are involved in national and macro level pricing decisions, production controls are created in fair and efficient ways, measures to prevent countries and farmers from free riding exist (Koning \& Jongeneel, 2008), measures to deal with excess production and how farmers are allocated quotas for remunerative cash crop, such that alternative, income earning opportunities for poor producers are available if farmers are not allowed to expand their production to earn a higher income.

\subsection{Interventions addressing food supply system activities}

\subsubsection{Context and market analyses for cost-effectiveness}

Interventions should include a context and market analysis to ensure effective value chains, without unbalancing supply and demand The likelihood of achieving impact at scale increases if projects start with a context analysis and a market analysis (Nutz, 2017; UNHCR, 2015). A context analysis includes a socio-economic analysis, providing information on the existing socio-economic situation of the target group and the community they live in. This should include information on their interests, aspirations, risk aversion, financial capabilities, and other aspects that may affect their decision making (Nutz, 2017; UNHCR, 2015). A market and value chain analysis is also necessary to assess the demand for services or products that may be generated through interventions focusing on diversification as well as supply chain logistics. For interventions focusing on productivity enhancement to work, the supply of inputs and access to input markets needs to be guaranteed at the right time with regard to the crop calendar. When the intervention focuses on service delivery, the demand for these services needs to be carefully assessed in addition to demand for the product. For all interventions, it is therefore important to consider the synergy between supply and demand, locally but if implemented at scale, also regionally or even globally. 
To facilitate farmers' behavioural change, interventions need to address contextual and personal factors The contextual factors shown in Fig. 3 can affect how increased income from agricultural production and off-farm activities interact. Interventions that address these barriers are therefore more likely to lead to behavioural change of farmers and therefore positively impact incomes in a cost effective way. In the interventions we studied, the focus was limited to community and farm level inputs, extension and financial services and in some cases, support to market produce, education and environmental protection. Most interventions focus on commodity income and some on diversification, while another focus may more relevant for farmer and his/her households. The same holds for the importance of addressing personal factors, as they also influence farmer and household decision-making processes. In the interventions studied, personal factors were not explicit in the intervention design. Taking farmers' and household's personal factors explicitly into account in design of interventions will enhance their effectiveness and efficiency.

\subsubsection{Price increases by companies}

One of the activities that supply chain companies such as traders, manufacturers and retail can do to increase incomes is to increase the farmgate price paid to farmers. As so many commodity farmers are poor, every price - and thus incomeincrease is worthwhile. Information about the potential for such price increases to achieve living incomes can be found in Sect. 3.3.1. In that section we conclude that for large groups of vulnerable farmers, high price increases will, even though they will increase incomes, not lead to such farmers earning a living income. The poorest farmers benefit least because of selling small volumes. Advantages and disadvantages of increasing prices can further be found in Sect. 4.1.5. Finally, a question is whether companies have enough financial room to increase payments significantly to the sometimes millions of farmers they source from, for instance by establishing a relatively high minimum farmgate price, decreasing price volatility. There is, however, an evidence gap with regard to such information.

\subsection{Interventions addressing environmental drivers}

\subsubsection{Agro-ecological and climatic conditions should be favourable for farmers to achieve a living income}

Environmental drivers are key for thriving food systems, but long and short term interests are conflicting Many commodity producers in lower- and middle-income countries are expected to experience the impacts of changes in climate (Centro Internacional de Agricultura Tropical, 2011;
Läderach et al., 2013; Masters et al., 2010; Ovalle-Rivera et al., 2015). To achieve sustainable changes in farmer incomes, a long-term perspective is needed. If according to climatic predictions it will no longer be possible to produce key commodities in a certain region in the future, these farmers must be guided in shifting their production to other activities or in earning income from off-farm sources. There are also other trade-offs between short- and long-term interests. An important example concerns deforestation. In cocoa farming, for example, much forested land has been converted to cocoa plantations in the past. The traditional shade management has been gradually replaced by full-sun monoculture (Franzen \& Mulder, 2007). Such full-sun, monocrop cocoa systems enhance yields in the short term but these yields may not be maintained in the long run. Farmers who are unaware of this, and farmers with a short time horizon can be inclined to opt for such a farming system, which leads to severe long-term soil nutrient degradation, in turn leading to very low levels of productivity in the long run, as the pressure on the land is too high to leave it fallow after 20 to 30 years of intensive use (Ruf, 2001).

\section{Conclusions and recommendations}

In this chapter we conclude on how different types of smallholder commodity farmers can be supported to achieve a living income and give recommendations for policymakers of public and private sector organisations for designing and implementing interventions to achieve this goal.

\subsection{A large proportion of smallholder cocoa and tea households do not have the potential to earn a living income without structural change}

Despite huge investments in improving the livelihoods of smallholder tree-crop commodity farmers in the past decades, there is still widespread poverty amongst coffee, cocoa, tea, and palm oil producers. The impact of interventions, if any, has not been sufficient for farmers to be lifted out of poverty at scale, nor has resulted in large groups of farmers earning a living income. Interventions that only address a single food system component (for instance productivity or price increases) have not lifted the majority of farmers above the extreme poverty benchmark. The reason for the lack of success is that in many cases the underlying poverty drivers were not addressed, such as land fragmentation, volatile prices, buying prices which do not cover all costs, farmers' lack of capacity to invest and difficulties for farmers to diversify income sources on-farm and off-farm (such as employment). A large proportion of cocoa and tea farmers for whom we have collected data therefore do not have the potential to earn a living income. 


\subsection{A starting point for short- to medium-term interventions for households without the potential to earn a living income should be to improve their resilience}

For farmers who do not have the possibility to improve their income, support could focus on a one health approach which embraces food security and nutrition (Walton et al., 2020, Arsyad et al., 2019), alternative on- and off-farm income and employment, and social assistance programmes. For those farmers it often does not make sense to focus efforts on commodity production. Therefore, depending on their circumstances, they can best be supported in finding employment, and improving their resilience through improving food production for home consumption, water, sanitation, hygiene as well as access to healthcare and education possibilities. Social assistance programmes such as cash transfers or basic income schemes should also be considered. This protects them against the likelihood of falling back to poverty if unexpected circumstances occur.

\subsection{Long term policies such on land governance, labour market development and social assistance should be considered, but even they do not necessarily guarantee a living income to be achieved}

If small farm sizes hamper many farmers in earning a decent income, rights-based land governance policies could be developed with participation from the concerned communities. Such policies need to take into account expected climate change effects as in many tree-crop commodity sectors it is expected that climatic conditions in major production zones will change in the future. Land policies should take into account forest and biodiversity protection and fragmentation on a landscape level and anticipate indirect, tele-coupled impacts from interventions. Together with facilitating household members to earn an income through employment (either within agriculture or other sectors), this could create opportunities for some farmers to increase their farm and improve incomes and for others to move out of selfemployed agriculture in this generation or the next. This is obviously not easily achieved as different stakeholders often have different priorities, and employment opportunities are not easily created and if so, people do not tend to easily move away from their community and social network. Also, being employed does not guarantee earning a living wage because minimum and prevailing wages are generally lower than a living wage. In addition, cash transfers and a Universal Basic Income are expected to increase incomes, but also do not guarantee earning a living income directly though indirect welfare effects could occur.

\subsection{There is no silver bullet to achieve a living income for all smallholder tree-crop commodity farmers because different groups of farmers need different types of support. The private sector, governments and NGOs all have a role to play}

As different types of farmers have different types of needs, there is no silver bullet to achieve a living income for all smallholder tree-crop commodity producers. Interventions by the private sector and NGOs can support many farmers achieving living incomes and support farmers and communities to increase resilience. But they generally cannot achieve living incomes for the most vulnerable farmers as many of the structural factors hampering income increases for such farmers are beyond their sphere of direct influence. Governments have an important role in addressing structural factors and, together with market parties, have a role in transforming the markets and thus prices locally, nationally and internationally. A shift towards more system-oriented strategies in multi-stakeholder setting appears most likely to benefit the scale and sustainability of impact.

\subsection{Achieving living incomes requires talking to farmers and their household members, coordination between stakeholders, sharing lessons learnt and data}

In assessing the potential for households to earn a living income from commodities the focus should be on whether farmers can reasonably be expected to reach a decent standard of living. It is important to talk to farmers about their needs, wants and aspirations, and take contextual and personal factors into account in designing interventions, within households and within communities. The effective implementation of diversified interventions requires coordination between all stakeholders active in a given region, landscape and/or value chain. Each stakeholder has their own strengths to contribute: buying companies can support those farmers for whom it is relevant with agronomic advice and input services, and work alongside other stakeholders (such as other supply chain actors for diversification) to improve the situation of their supplying farmer households who cannot improve commodity income. Improving land governance, health care, education, water, sanitation and food security is generally the role of governments, as are social assistance programmes. Interventions focusing on price and supply management are generally the domain of both governments and private sector. To assess whether households have the potential for earning a living income based on a specific commodity cash crop, there is a need for data sharing to limit the burden of farmers being asked the same questions 
multiple times. Data disaggregated by especially gender, but also age and other socio-demographic characteristics can aid to close the current data gap.

\section{Appendix 1 Information from the literature review on the impact of interventions on crop and household income}

\section{Contract farming}

The systematic review finds that the effects are positive $(\mathrm{RR}=1.32$ on household income -8 studies, $\mathrm{RR}=1.65$ on farming income -6 studies, $R R=1.92$ on contracted crop income -12 studies). However, there seems to be a very large selection and survivor bias, with a high likelihood of an overestimation of effects. However, the authors note that it is likely that the effects will be significant regardless, as smallholders would not give up their farming autonomy (or maintain doing so over the years) if they would not be (Ton et al., 2017).

\section{Standards and certification}

The systematic review finds the effects on the total household income of farmers are unclear (= coffee (3), cocoa, banana, horticulture, black pepper, other; 8 studies in total). While household incomes of farmers engaged in certified production were $6 \%$ higher than those of households not engaged in certified production, the overall effect is not statistically significant ( $\mathrm{SMD}=0.13$ ). The effect size estimated for individual studies range from negative to positive, though all statistically significant studies provided positive estimates. Effects on crop income (=coffee (4), horticulture (2), cocoa (2), tea, other) were positive and statistically significant $(\mathrm{SMD}=0.22)$. Incomes from the sale of produce were $11 \%$ higher if the produce was certified (Oya et al., 2017). The Farmer Income Lab (3 sources assessed in detail) identifies this as medium income impact (10-50\% income increases) with demonstrated limited impact on income enabling factors (high scale, medium durability) (Dalberg \& Wageningen University, 2018).

\section{Cash transfers}

The systematic review examined nine studies with impacts on poverty measures (poverty headcount, poverty gap), out of which about $2 / 3$ rds find a significant impact. While cash transfers were shown to lead to an increase of total and food expenditure for most programmes, it appears that in many cases this impact is not big enough to have an effect on aggregate poverty levels. Findings range from about 4 percentage points to 8 or 9 percentage points, depending on the measure of poverty. But, the long term effects are not clear yet (Bastagli et al., 2016).

\section{Agricultural input subsidies}

The systematic review finds that the effect of receiving fertiliser and seed subsidies on income and household expenditures, on average, is 0.15 (significant). All studies included ( 3 sources in total) report a positive impact, but there is a high degree of between-study variability, which is most likely caused by the different outcome variables between the studies. The effect sizes for income and expenditures are smaller than those for revenue. Two studies on seed inputs for maize crops measured the effects on poverty, one found an 11 percent decrease in the numbers of farmers living beneath the USD 1.25 poverty line and a smaller 7 per cent decrease in those living beneath the USD 2.00 poverty line, whereas the other found no significant effect on the severity of farm household poverty (the degree of inequality below the poverty line). The meta-regressions also show small, negative relationships between subsidy size and yield as well as between subsidy size and income. However, these relationships are not statistically significant. Consequently, the meta-regression analysis provides no evidence of an association (positive or negative) between subsidy size and agricultural outcomes (Hemming et al., 2018). The Farmer Income Lab identifies input subsidies (24 sources assessed in detail) as an intervention that did not show significant income increases $(<10 \%)$. The scale was identified as high, durability as low (Dalberg \& Wageningen University, 2018).

\section{Access to finance}

The Farmer Income Lab (Dalberg \& Wageningen University, 2018) (13 sources assessed in detail) identified this as medium income impact at scale with demonstrated impact on income enabling factors. Interventions demonstrated income increases of $15 \%$ on average and the ability to reach between 2,100 and 400,000 clients. These programs are effective because they: 1) segmented farmers, 2) tailored solutions to farmers, 3) leveraged farmer aggregation, and 4) bundled services.

\section{Productivity enhancement through training \& input services}

Many projects focus have a primary focus on increasing farmer productivity, as it is thought to benefit both the buying companies as well as the farmers. The assumption behind such projects is that farmer productivity leads to increases in farmer profits and/or household incomes, however the effect of such projects on household income is not always as clear as expected. The adoption of good agricultural practices, including sustainable agricultural practices, is frequently associated with increases in (household) income (see e.g.: Ali \& Abdulai, 2010; Amare et al., 2012; Asfaw et al., 
2016, 2019; Kassie et al., 2018; Noltze et al., 2013; Pray \& Huang, 2003; Teklewold et al., 2013). However, the question remains whether training and/or input services lead to actual changes in the adoption of practices and, if yes, for how long. Moreover, the adoption of good agricultural practices is also often associated with increases in costs of production, which is also yields some studies that find no changes in household income (Takahashi \& Barrett, 2014) or profits (Takahashi et al., 2019) due to these increased costs, or even negative effects on income (Daniel et al., 2010). Moreover, if all farmers would have increases in yields, the prices might decrease in the long run, eliminating any income effects for farmers. The Farmer Income Lab classifies productivity enhancement as a mixed evidence of impact, demonstrating between $10-50 \%$ income improvements, with medium reach and durability (Dalberg \& Wageningen University, 2018).

\section{Farmer field schools}

The most common strategies for productivity enhancement are providing training in agricultural practices and providing input services, which are also frequently combined in projects. The approaches to reaching farmers can differ. Many projects provide their services directly via cooperatives, while others use a more bottom up approach and use Farmer Field Schools (FFSs) to disseminate knowledge. A systematic review on FFSs found that a significant increase in agricultural yields was found, by 13 per cent over comparison farmers ( $R R=1.13,11$ studies). They also found a significant increase in profits (net revenues), by 19 per cent among FFS participants over comparison farmers $(\mathrm{RR}=1.19,2$ studies). They mention that the increase in profits was higher for FFS projects which also included complementary interventions involving input or marketing support ( $R R=2.51,2$ studies) (Waddington et al., 2014). It is important to note here that commodity profits do not directly translate to significant increases in total household income, which is not something that was included in the studies reviewed. The Farmer Income Lab identifies FFSs as an intervention with mixed evidence of impact, as it demonstrates between $10-50 \%$ income improvements, with high reach but low durability (Dalberg \& Wageningen University, 2018).

\section{Appendix 2 Calculating poverty lines and living income benchmarks to compare data between countries}

\section{Living income benchmark calculations}

For each country, household incomes were converted to match the living income benchmark:
- Ghana: (Smith \& Sarpong, 2018)

- Cocoa Côte d'Ivoire: (Tyszler et al., 2018)

- Kenya: (Anker \& Anker, 2015)

The monthly living income benchmarks were converted to the year of each dataset using the changes over time in the consumer price index. The living income benchmark is based upon a country specific average family size (6 in Côte d'Ivoire, 5 in Ghana, 5.5 in Kenya). Therefore, yearly household income from each of the datasets was adjusted only for the period: it was divided by 12 to change the data from yearly to monthly income. For comparison with the World Bank poverty line, the monthly living income line per family was converted to a daily living income per household member. By doing so, we treated adults and children in the households in the same way, not correcting for male or female equivalent FTE values. We did not deduct from the benchmark figures the value of food produced for home consumption, as such information was not available. Therefore, we assume all farmers buy all food. As farmers likely produce some food themselves, this assumption creates an overestimation of the living income gap in our calculations.

Finally, the living income benchmark was adjusted to the year of the surveys using changes in the consumer price indices. After correction, the living income benchmark is equivalent to CFA 1,450 per person per day for Côte d'Ivoire in 2017, to 5.747 Cedi per person per day in Ghana in 2014 and to 135.94 Kenyan Shillings per person per day in Kenya in 2015 .

\section{Poverty line benchmark calculations}

For each country, household incomes were converted to match the poverty line of USD 1.90 per person per day (2011 PPP). This poverty line was set in 2011 , and was adjusted to the year of the data and local currencies using the PPP conversion factor of 2011 and the changes in time using the consumer price index, following the methodology as used by USAID (Sillers, 2005). After correction, the USD 1.90 poverty line is equivalent to CFA 480 in 2017 for Côte d'Ivoire, to 2.068 Cedi in 2014 for Ghana, and to 73.63 Kenyan Shillings in 2015 for Kenya. The yearly household level income data was converted to daily income by dividing by 365 , and then divided by the number of household members.

\section{Appendix 3 Calculations on the effect of price increases on income}

The ICCO daily price was USD $2501 /$ tonne on 18 September 2020 (ICCO, 2020). The Living Income Differential by the governments of Ivory Coast and Ghana in 2019 translates to USD 400/tonne on all 2020/2021 season cocoa contracts, 
on top of the market price (Angel et al., 2019; Vidzraku, 2018). This is a $16 \%$ increase compared to a market price of USD 2501/Mt. The mean income of farmers earning under the living income benchmark as well as under the World Bank extreme poverty line (USD 1.90 PPP) in Ghana is USD 0.27 per person per day, out of which $84 \%$ stems from cocoa farming (Waarts et al., 2015). A $16 \%$ increase on $84 \%$ of USD 0.27 generates a new income of USD 0.307 per person per day, which is an increase of USD 13.3 per person per year compared to a situation without the Living Income Differential.

The minimum Sustainability Differential as announced by Rainforest Alliance is USD 70/Mt (Rainforest Alliance, n.d.), which is a $3 \%$ increase compared to a market price of USD $2501 / \mathrm{Mt}$. A $3 \%$ increase on $84 \%$ of USD 0.27 generates a new income of USD 0.277 per person per day, which is an increase of USD 2.5 per person per year compared to a situation without the Living Income Differential.

Acknowledgements This article is derived from a chapter of the Rural Development Report 2021 [Waarts, Y., V. Janssen, R. Aryeetey, D. Onduru, D. Heriyanto, S. Tin Aprillya, A. N' Guessan, L. Courbois, D. Bakker, 2021. How can different types of smallholder commodity farmers be supported to achieve a living income?]. We are grateful to Solidaridad, UTZ (now Rainforest Alliance), Nestlé, IDH, KTDA, Unilever and Wageningen University \& Research (WUR), for sharing their datasets and/or answering our questions. We thank the farmers and stakeholders in the value chains interviewed in these studies. We acknowledge the IFAD funded project 2000002862 and Wageningen University \& Research for funding this research.

Funding Funding for this research was provided by IFAD (project 2000002862) and Wageningen University \& Research.

Data availability UTZ (now Rainforest Alliance) consented to use data on behalf of all the funders of the cocoa studies.

Code availability All calculations and analyses for graphs were conducted using Stata 14. Code is available on request.

\section{Declarations}

Competing interests The authors declare no conflict of interest.

Open Access This article is licensed under a Creative Commons Attribution 4.0 International License, which permits use, sharing, adaptation, distribution and reproduction in any medium or format, as long as you give appropriate credit to the original author(s) and the source, provide a link to the Creative Commons licence, and indicate if changes were made. The images or other third party material in this article are included in the article's Creative Commons licence, unless indicated otherwise in a credit line to the material. If material is not included in the article's Creative Commons licence and your intended use is not permitted by statutory regulation or exceeds the permitted use, you will need to obtain permission directly from the copyright holder. To view a copy of this licence, visit http://creativecommons.org/licenses/by/4.0/.

\section{References}

Abbott, P. C., Wilcox, M., \& Muir, W. A. (2005). Corporate social responsibility in international cocoa trade. Purdue University.

AFD Land Tenure and Development Technical Committee. (2015). Formalizing Land Rights in Developing Countries: Moving from Past Controversies to Future Strategies. Ministère des Affaires étrangères et du Développement international.

Akiyama, T., \& Varangis, P. N. (1990). The impact of the International Coffee Agreement on producing countries. The World Bank Economic Review, 4(2), 157-173.

Ali, A., \& Abdulai, A. (2010). The adoption of genetically modified cotton and poverty reduction in Pakistan. Journal of Agricultural Economics, 61(1), 175-192.

Alvarez, G., \& Von Hagen, O. (2011). The impacts of private standards on producers in developing countries: literature review series on the impacts of private standards, part II. Part II (December 1, 2011).

Amare, M., Asfaw, S., \& Shiferaw, B. (2012). Welfare impacts of maize-pigeonpea intensification in Tanzania. Agricultural Economics, 43(1), 27-43.

Angel, M., Aboa, A., \& Hunt, N. (2019). Ivory Coast, Ghana strike first cocoa deals with living income premium. Reuters. https:// www.reuters.com/article/cocoa-west-africa-pricepremiumidUSL5N2644FR

Anker, R, \& Anker, M. (2015). Living wage report Kenya: with a focus on rural Mount Kenya Area. Prepared for: The Global Living Wage Coalition.

Anker, R., \& Anker, M. (2017). Living wages around the world: Manual for measurement. Edward Elgar Publishing.

Arsyad, D. S., Nasir, S., Arundhana, A. I., Phan-Thien, K. -Y., Toribio, J. -A., McMahon, P., et al. (2019). A one health exploration of the reasons for low cocoa productivity in West Sulawesi. One Health, 8, 100107.

Asfaw, S., Di Battista, F., \& Lipper, L. (2016). Agricultural technology adoption under climate change in the Sahel: micro-evidence from Niger. Journal of African Economies, 25(5), 637-669.

Asfaw, S., Scognamillo, A., Di Caprera, G., Sitko, N., \& Ignaciuk, A. (2019). Heterogeneous impact of livelihood diversification on household welfare: cross-country evidence from Sub-Saharan Africa. World Development, 117, 278-295.

Atwood, D. A. (1990). Land registration in Africa: the impact on agricultural production. World Development, 18(5), 659-671.

Babatunde, R. O., \& Qaim, M. (2010). Impact of off-farm income on food security and nutrition in Nigeria. Food Policy, 35(4), 303-311.

Banerjee, A., Niehaus, P., \& Suri, T. (2019). Universal basic income in the developing world. Annual Review of Economics.

Banerjee, A. V, \& Duflo, E. (2019). Good economics for hard times: Better answers to our biggest problems. Penguin UK.

Bastagli, F., Hagen-Zanker, J., Harman, L., Barca, V., Sturge, G., Schmidt, T., \& Pellerano, L. (2016). Cash transfers: What does the evidence say. A rigorous review of programme impact and the role of design and implementation features. ODI.

Bernstein, J., Johnson, N., \& Arslan, A. (2019). Meta-evidence review on the impacts of investments in agricultural and rural development on sustainable development goals 1 and 2. IFAD Research Series, 38, 1-80.

Bonjean, C. A., \& Brun, J. -F. (2016). Concentration and Price Transmission in the Cocoa-Chocolate Chain. The Economics of Chocolate, 339.

Boone, C. (2019). Legal empowerment of the poor through property rights reform: tensions and trade-offs of land registration and titling in sub-Saharan Africa. The Journal of Development Studies, 55(3), 384-400. 
Bulte, E., Beekman, G., Di Falco, S., Hella, J., \& Lei, P. (2014). Behavioral responses and the impact of new agricultural technologies: evidence from a double-blind field experiment in Tanzania. American Journal of Agricultural Economics, 96(3), 813-830.

Bymolt, R., Laven, A., \& Tyzler, M. (2018). Demystifying the cocoa sector in Ghana and Côte d'Ivoire. The Royal Tropical Institute (KIT): Amsterdam, The Netherlands.

Centro Internacional de Agricultura Tropical, C. (2011). Future climate scenarios for Kenya's tea growing areas: final report Cali, Managua: april 2011 [Online].

Chang, H. -J. (2007). Institutional change and economic development: An introduction. Institutional change and economic development, 22-23.

Chiwaula, L., Anker, R., \& Anker, M. (2020). Update of Living Wage and Actual Wages of Tea Workers in Malawi.

CIRES. (2018). Living Income Report Rural Côte d'Ivoire Cocoa growing areas. Ivory Coast.

Conley, T. G., \& Udry, C. R. (2010). Learning about a new technology: pineapple in Ghana. American Economic Review, 100(1), 35-69.

COSA and KIT. (n.d.). Guidance on calculating household income. Version 1. Prepared for the Living Income Community of Practice. 2020

Dalberg \& Wageningen University. (2018). What works to increase smallholder farmers' income? A landscape review. Farmer income lab. https://www.farmerincomelab.com/sites/g/files/ jydpyr621/files/2019-09/What_Works_FINAL_9.19.pdf

Daniel, J. D., Sanda, A. A., \& Adebayo, E. F. (2010). Net income analysis and efficiency of resource use among cotton farmers in the Southern part of Adamawa State Nigeria. Agric Biol JN Am, 1(6), 1215-1222.

Dedehouanou, S. F. A., Araar, A., Ousseini, A., Harouna, A. L., \& Jabir, M. (2018). Spillovers from off-farm self-employment opportunities in rural Niger. World Development, 105, 428-442.

Demetriou, D. (2013). The development of an integrated planning and decision support system (IPDSS) for land consolidation. Springer Science \& Business Media.

Department of Agrarian Reform. (2019). Sugar block farming helps double yield. Republic of the Philippines. https://www.dar.gov. ph/articles/features/101186. Accessed 29 Sept 2020.

Duflo, E., \& Banerjee, A. V. (2020). Coronavirus is a crisis for the developing world, but here's why it needn't be a catastrophe. The Guardian. https://www.theguardian.com/commentisfree/2020/ may/06/vulnerable-countries-poverty-deadly-coronavirus-crisis

Egger, D., Haushofer, J., Miguel, E., Niehaus, P., \& Walker, M. W. (2019). General equilibrium effects of cash transfers: experimental evidence from Kenya. National Bureau of Economic Research.

Fisher, T., \& Hostland, D. (2002). The long view: labour productivity, labour income, and living standards in Canada. The Review of Economic Performance and Social Progress, 2.

FPA. (2020). Liberia: land authority grants 6 communities full ownership of ancestral land in Lofa. https://frontpageafricaonline.com/ county-news/liberia-land-authority-grants-6-communities-fullownership-of-ancestral-land-in-lofa/. Accessed 29 Sept 2020.

Franzen, M., \& Mulder, M. B. (2007). Ecological, economic and social perspectives on cocoa production worldwide. Biodiversity and Conservation, 16(13), 3835-3849.

Giller, K. E., Delaune, T., da Silva, J., Descheemaeker, K., van de Ven, G., Schut, T. et al. (n.d.). The Future of Farming: Who will produce our food? Wageningen University.

Global living wage coalition. (2020). https://www.globallivingwage. org. Accessed 1 Oct 2020.

Greiner, R., Patterson, L., \& Miller, O. (2009). Motivations, risk perceptions and adoption of conservation practices by farmers. Agricultural Systems, 99(2-3), 86-104.

Grillo, J. (2018). From Living Wage to Living Income. Considerations for the use of the Anker methodology for calculating living wages to inform living income estimates.
Hemming, D. J., Chirwa, E. W., Dorward, A., Ruffhead, H. J., Hill, R., Osborn, J., et al. (2018). Agricultural input subsidies for improving productivity, farm income, consumer welfare and wider growth in low-and lower-middle-income countries: a systematic review. Campbell Systematic Reviews, 14(1), 1-153.

ICCO. (2018). Berlin Declaration of the Fourth World Cocoa Conference. https://www.icco.org/about-us/icco-news/387-berlin-declaration-ofthe-fourth-world-cocoa-conference.html. Accessed 29 Sept 2020.

ICCO. (2020). ICCO Daily Prices of Cocoa Beans. https://www.icco. org/statistics/cocoa-prices/daily-prices.html. Accessed 18 Sept 2020.

IDH. (n.d.). Production, Protection \& Inclusion: public private governance models for green and inclusive growth in sourcing areas. https://www.idhsustainabletrade.com/approach/production-prote ction/. Accessed 29 Sept. 2020.

IFPRI Ghana. (n.d.). Institutional alternatives to implement block farming. http://gssp.ifpri.info/institutional-alternatives-to-implementblock-farming/. Accessed 29 Sept 2020.

Impact Institute. (n.d.). Estimating farmer household income; How to use secondary data to estimate farmer household income illustrated by two specific use case scenarios. V1.2. 2020.

Ingram, V. J. (2021). The tropical mixed tree and food crop food systems in West Africa. In B. J. De Steenhuijsen-Piters, B. Nelen, V. Wennink, V. J. Ingram, F. Tondel, F. Kruijssen, \& J. Aker (Eds.), West African Food System Resilience (pp. 138-162). https://edepot.wur.n1/543127

Ingram, V. J., van Rijn, F., Waarts, Y., Dekkers, M., de Vos, B., Koster, T., et al. (2018). Towards sustainable cocoa in Côte d'Ivoire: The impacts and contribution of UTZ certification combined with services provided by companies. Wageningen Economic Research.

Ingram, V. J., Waarts, Y., Ge, L., van Vugt, S. M., Wegner, L., \& Puister-Jansen, L. F. (2014). Impact of UTZ certification of cocoa in Ivory Coast. Assessment framework and baseline. LEI Wageningen UR.

International Food Policy Research Institute (IFPRI). (2020). 2020 Global Food Policy Report: Building Inclusive Food Systems. Washington, DC: International Food Policy Research Institute (IFPRI). https://doi.org/10.2499/9780896293670

Iram, U., \& Butt, M. S. (2004). Determinants of household food security. International Journal of Social Economics.

Kandpal, E. (2019). In Fighting Poverty, Cash Transfer Programs Should Be Wary of Negative Spillovers. World Bank. https:// www.worldbank.org/en/news/feature/2019/12/27/cash-transferprograms-should-be-wary-of-negative-spillovers. Accessed 1 Oct 2020.

Kassie, M., Marenya, P., Tessema, Y., Jaleta, M., Zeng, D., Erenstein, O., \& Rahut, D. (2018). Measuring farm and market level economic impacts of improved maize production technologies in Ethiopia: evidence from panel data. Journal of Agricultural Economics, 69(1), 76-95.

Kavoi, M. M., Owuor, P. O., \& Siele, D. K. (2002). Minimum tea hectarage hypothesis: the case of smallholder tea sub-sector in Kenya. Journal of Agriculture, Science and Technology, 4(1), 1-14.

Kennedy, E., \& Peters, P. (1992). Household food security and child nutrition: the interaction of income and gender of household head. World Development, 20(8), 1077-1085.

Kimbugwe, K. (2020). A New Leaf: Transforming livelihoods through the tea industry. https://www.enterprise-development.org/wp-content/ uploads/A-New-Leaf-Transforming-livelihoods-through-the-teaindustry.pdf

Koning, N., \& Jongeneel, R. (2008). La CEDEAO peut-elle créer un OPEP du cacao durable? Revue Tiers Monde, 3, 661-681.

Läderach, P., Martinez-Valle, A., Schroth, G., \& Castro, N. (2013). Predicting the future climatic suitability for cocoa farming of the world's leading producer countries Ghana and Côte D'ivoire. Climatic Change, 119(3), 841-854. 
Masters, G., Baker, P., \& Flood, J. (2010). Climate change and agricultural commodities. CABI Work Pap, 2, 1-38.

Matenga, C. R. (2017). Outgrowers and livelihoods: The case of Magobbo smallholder block farming in Mazabuka District in Zambia. Journal of Southern African Studies, 43(3), 551-566.

Minos, D. (2018). Analysis using International and National Poverty Lines as a proxy for a Living Income benchmark.

Molina, G. G., \& Ortiz-Juarez, E. (2020). Temporary Basic Income: Protecting Poor and Vulnerable People in Developing Countries. United Nations Development Program.

Nicavera, E. P. (2018). DAR pushes for more sugar block farms in Negros Occidental. SunStar. https://www.sunstar.com.ph/article/ 1502659/Bacolod/Business/DAR-pushes-for-more-sugar-blockfarms-in-Negros-Occidental

Noltze, M., Schwarze, S., \& Qaim, M. (2013). Impacts of natural resource management technologies on agricultural yield and household income: the system of rice intensification in Timor Leste. Ecological Economics, 85, 59-68.

Notess, L., Veit, P., Monterroso, I., Sulle, E., Larson, A. M., Gindroz, A. -S., et al. (2020). Community land formalization and company land acquisition procedures: a review of 33 procedures in 15 countries. Land Use Policy, 104461.

Nutz, N. (2017). A Guide to Market-Based Livelihood Interventions for Refugees.

Oomes, N., Tieben, B., Laven, A., Ammerlaan, T., Appelman, R., Biesenbeek, C., \& Buunk, E. (2016). Market concentration and price formation in the global cocoa value chain. SEO-rapport, (2016-79).

Ortiz, I., Behrendt, C., Acuña-Ulate, A., \& Anh, N. Q. (2018). Universal Basic Income proposals in light of ILO standards: Key issues and global costing. Available at SSRN 3208737.

Ovalle-Rivera, O., Läderach, P., Bunn, C., Obersteiner, M., \& Schroth, G. (2015). Projected shifts in Coffea arabica suitability among major global producing regions due to climate change. PLoS One, 10(4), e0124155.

Oya, C., Schaefer, F., Skalidou, D., McCosker, C., \& Langer, L. (2017). Effects of certification schemes for agricultural production on socio-economic outcomes in low-and middle-income countries: a systematic review. Campbell Systematic Reviews, 13(1), 1-346.

Page, J., \& Shimeles, A. (2015). Aid, employment and poverty reduction in Africa. African Development Review, 27(S1), 17-30.

Page, J., \& Söderbom, M. (2015). Is small beautiful? Small enterprise, aid and employment in Africa. African Development Review, 27(S1), 44-55.

Pantoja, B. R., Alvarez, J. V., \& Sanchez, F. A. (2019). Implementing Sugarcane Block Farming for Increased Farm Income and Productivity.

PEF. (2016). The Negros Block Farming Project: Building 'bigger' farms in Negros Occidental. https://pef.ph/index.php/2016/03/ 16/the-negros-block-farming-project-building-bigger-farms-innegros-occidental/. Accessed 29 Sept 2020.

Pray, C., \& Huang, J. (2003). The impact of Bt cotton in China. In The economic and environmental impacts of Agbiotech (pp. 223-242). Springer.

Prokopy, L. S., Floress, K., Klotthor-Weinkauf, D., \& Baumgart-Getz, A. (2008). Determinants of agricultural best management practice adoption: evidence from the literature. Journal of Soil and Water Conservation, 63(5), 300-311.

Purcell, T. F. (2018). 'Hot chocolate': financialized global value chains and cocoa production in Ecuador. The Journal of Peasant Studies, 45(5-6), 904-926. https://doi.org/10.1080/03066150.2018. 1446000 .

Putzel, L., Kelly, A. B., Cerutti, P. O., \& Artati, Y. (2015). Formalization as development in land and natural resource policy. Society \& Natural Resources, 28(5), 453-472.
Rainforest Alliance. (n.d.). 2020 Certification program. https://www. rainforest-alliance.org/business/tag/2020-certification-program/. Accessed 25 Sept 2020.

Rainforest Alliance. (2020). FAQ: Does Rainforest Alliance Certification Guarantee a Minimum Price for Certified Crops? https://www. rainforest-alliance.org/faqs/does-rainforest-alliance-certifiedguarantee-minimum-price. Accessed 25 Sept 2020.

Ruf, F. (2001). Tree crops as deforestation and reforestation agents: the case of cocoa in Côte d'Ivoire and Sulawesi. Agricultural Technologies and Tropical Deforestation, 2001, 291-315.

Shakhovskoy, M., Colina, C., \& Höök Clason, M. L. (2019). Pathways to prosperity. Rural and Agricultural Finance State of the Sector Report 2019.

Shiferaw, B. A., Okello, J., \& Reddy, R. V. (2009). Adoption and adaptation of natural resource management innovations in smallholder agriculture: reflections on key lessons and best practices. Environment, Development and Sustainability, 11(3), 601-619.

Sillers, D. (2005). Annex: Calculating PPP Conversion Factors and '\$1-a-day'Poverty Lines. povertyfrontiers.org/ev.php

Smith, S., Anker, M., \& Anker, R. (2017). Living wage report Ghana lower Volta area: context provided in the banana sector. The Global Living Wage Coalition, 1(14).

Smith, S., \& Sarpong, D. (2018). Living income report rural Ghana. Cocoa growing areas of Ashanti, Central, Eastern, and Western Regions. The Living Income Community of Practice, 1(1).

Squicciarini, M. P., \& Swinnen, J. (2016). The economics of chocolate. Oxford University Press.

Stein, H., \& Cunningham, S. (2017). Formalization and land grabbing in Africa: facilitation or protection? Tanzania Journal of Development Studies, 15(1-2), 1-31.

Takahashi, K., \& Barrett, C. B. (2014). The system of rice intensification and its impacts on household income and child schooling: evidence from rural Indonesia. American Journal of Agricultural Economics, 96(1), 269-289.

Takahashi, K., Mano, Y., \& Otsuka, K. (2019). Learning from experts and peer farmers about rice production: experimental evidence from Cote d'Ivoire. World Development, 122, 157-169.

Teklewold, H., Kassie, M., Shiferaw, B., \& Köhlin, G. (2013). Cropping system diversification, conservation tillage and modern seed adoption in Ethiopia: impacts on household income, agrochemical use and demand for labor. Ecological Economics, 93, 85-93.

Ton, G., Desiere, S., Vellema, W., Weituschat, S., \& D'Haese, M. (2017). The effectiveness of contract farming for raising income of smallholder farmers in low-and middle-income countries: a systematic review. Campbell Systematic Reviews, 13(1), 1-131.

Tony's Chocolonely. (2020). Unwrapping the true cost of poverty. https:// tonyschocolonely.com/nl/en/our-mission/news/unwrapping-thetrue-cost-of-poverty. Accessed 22 Sep 2021.

Tothmihaly, A. (2017). How low is the price elasticity in the global cocoa market? GlobalFood Discussion Papers.

Tröster, B., Staritz, C., Grumiller, J., \& Maile, F. (2019). Commodity dependence, global commodity chains, price volatility and financialisation: Price-setting and stabilisation in the cocoa sectors in Côte d'Ivoire and Ghana. Working Papers 62. Österreichische Forschungsstiftung für Internationale Entwicklung (ÖFSE) / Austrian Foundation for Development Research.

Tyszler, M., Bymolt, R., \& Laven, A. (2018). Analysis of the income gap of cocoa producing households in Côte d'Ivoire. KIT Royal Tropical Institute, Amsterdam, The Nerherlands.

Ugwu, C. (2020). Cyril Ugwu. IDH. https://www.idhsustainabletrade. com/publication/block-farming-model/. Accessed 29 Sept 2020.

UNHCR. (2015). Operational Guidelines on the Minimum Criteria for Livelihoods Programming.

United Nations. (2020). The Sustainable Development Goals Report 2020. 
van Berkum, S., Dengerink, J., \& Ruben, R. (2018). The food systems approach: sustainable solutions for a sufficient supply of healthy food. Wageningen Economic Research.

van de Ven, G. W. J., de Valença, A., Marinus, W., de Jager, I., Descheemaeker, K. K. E., Hekman, W. et al. (2020). Living income benchmarking of rural households in low-income countries. Food Security, 1-21.

van Vliet, J. A., Slingerland, M. A., Waarts, Y. R., \& Giller, K. E. (n.d.). A Living Income for cocoa producers in Côte d'Ivoire and Ghana?

Vidzraku, S. (2018). Cacao: Abidjan et Accra decident d' instituer un prix plancher commun. La Tribune. https://afrique.latribune.fr/ entreprises/agriculture/2018-12-17/cacao-abidjan-et-accradecident-d-instituer-un-prix-plancher-commun-801302.html

Voora, V., Bermúdez, S., \& Larrea, C. (2019a). Global Market Report: Cocoa. Winnipeg. https://www.iisd.org/system/files/publications/ ssi-global-market-report-cocoa.pdf

Voora, V., Bermúdez, S., \& Larrea, C. (2019b). Global Market Report: Coffee. Winnipeg. https://www.iisd.org/system/files/publications/ ssi-global-market-report-coffee.pdf

Voora, V., Bermúdez, S., \& Larrea, C. (2019c). Global Market Report: Tea. Winnipeg. https://www.iisd.org/system/files/publications/ ssi-global-market-report-tea.pdf

Voora, V., Larrea, C., Bermúdez, S., \& Baliño, S. (2019d). Global Market Report: Palm Oil. Winnipeg. https://www.iisd.org/system/ files/publications/ssi-global-market-report-palm-oil.pdf

Voora, V., Bermúdez, S., \& Larrea, C. (2020a). Global Market Report: Sugar. Winnipeg. https://www.iisd.org/system/files/publications/ ssi-global-market-report-sugar.pdf

Voora, V., Larrea, C., \& Bermúdez, S. (2020b). Global Market Report: Cotton. Winnipeg. https://www.iisd.org/system/files/publicatio ns/ssi-global-market-report-cotton.pdf

Waarts, Y., Dengerink, J., Puister-Jansen, L., van Rijn, F., \& Onduru, D. (2016). Final impact evaluation of Farmer Field School implementation in the smallholder tea sector in Kenya, 20092016. Wageningen Economic Research.

Waarts, Y., Ingram, V., Linderhof, V., Puister-Jansen, L., van Rijn, F., \& Aryeetey, R. (2015). Impact of UTZ certification on cocoa producers in Ghana, 2011 to 2014. LEI Wageningen UR.

Waarts, Y., Janssen, V., Ingram, V. J., Slingerland, M. A., van Rijn, F. C., Beekman, G. et al. (2019). A living income for smallholder commodity farmers and protected forests and biodiversity: how can the private and public sectors contribute?: White Paper on sustainable commodity production. Wageningen Economic Research.

Waddington, H., Snilstveit, B., Hombrados, J., Vojtkova, M., Phillips, D., Davies, P., \& White, H. (2014). Farmer field schools for improving farming practices and farmer outcomes: a systematic review. Campbell Systematic Reviews, 10(1), i-335.

Walton, M., Hall, J., Guest, D., Butubu, J., Vinning, G., Black, K., \& Beardsley, J. (2020). Applying one health methods to improve cocoa production in Bougainville: a case study. One Health, 10, 100143

Wessel, M., \& Quist-Wessel, P. M. F. (2015). Cocoa production in West Africa, a review and analysis of recent developments. NJASWageningen Journal of Life Sciences, 74, 1-7.

Woodhill, J., Saher, H., \& Griffith, A. (2020). Farmers and food systems: What future for small-scale agriculture?

Yaïche, M. M. (2019). Structural transformation, economic growth, and employment creation in Africa: an empirical analysis. International Journal of English Literature and Social Sciences (IJELS), $4(2)$

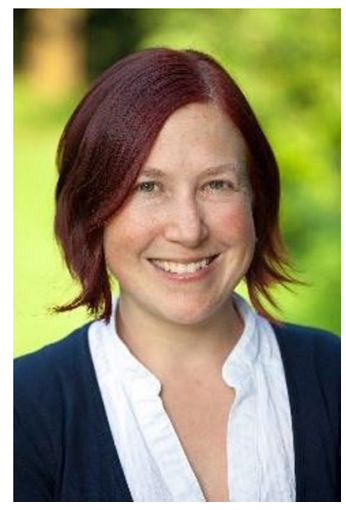

Yuca Waarts is an agricultural and environmental economist at Wageningen Economic Research in the Netherlands. She is an expert in evaluating the impact of innovations and services in agricultural and development programmes geared towards improving the livelihoods of smallholder farmers and workers. Yuca's key topic of research is evaluating the impact of innovations and interventions such as certification, training programmes and service delivery aimed at smallholder producers and workers in developing countries. Evaluations she leads or has led include: i) the IDH programme evaluation 2016-2020 first assessment report; ii) cocoa service delivery in evaluations in multiple countries for the private sector (Cameroon, Ghana, Ivory Coast, Indonesia, Brazil, Ecuador), iii) tea Farmer Field School and certification programs in Kenya, Malawi, Tanzania, Rwanda and South Africa (Rooibos), iv) Better Cotton Initiative in India, Mali and Pakistan, v) Bananas in Ghana and Dominican Republic), vi) vegetables (Indonesia) and vii) palm oil (ex-ante evaluation Indonesia).

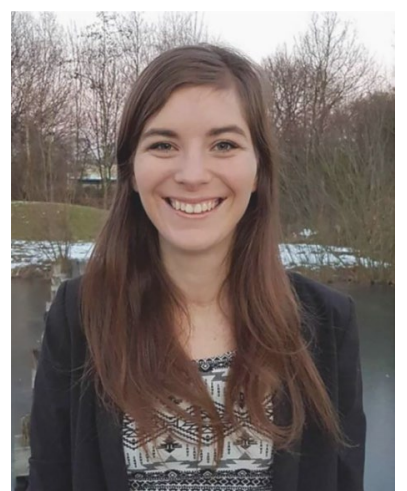

Valerie Janssen is a development economist and anthropologist at Wageningen Economic Research. Her work mostly focuses on the design and execution of impact evaluations of a wide range of interventions, ranging from projects aimed at the adoption and use of improved agricultural technologies and practices by smallholder farmers engaged in various tropical commodity chains (e.g. cocoa, tea, sugarcane), to the acceleration of start-ups and offering business development services to impactdriven small and medium-sized enterprises in developing countries. She also has proven track record in research on food security as well as evaluations of projects with a large food security component. In her work she makes use of her extensive knowledge on and experience analysing field data using either quantitative or qualitative research methods, as well as the integration of both.

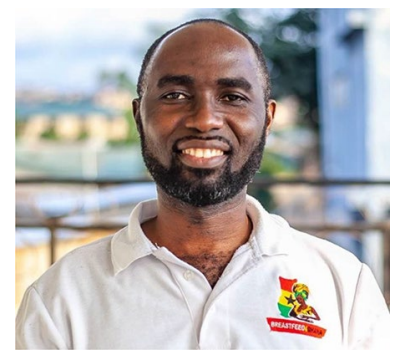

Richmond Aryeetey is an Associate Professor at the University of Ghana. Richmond is leading the Ghana Stories of Change in Nutrition work for Transform Nutrition West Africa and has worked in Ghana as a researcher in maternal and child health for the last 13 years. His expertise spans Primary research skills, formative research, and Monitoring and Evaluation, Training and Facilitation. Richmond's current research projects include studies on food environment of urban-dwelling adolescents, and exploring policy options for scaling up optimal feeding among infants and young children in Ghana. 


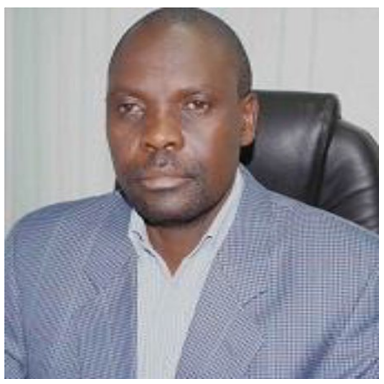

Davies Onduru is an agronomist with a background on Sustainable Agriculture and Rural Development and horticulture. Over time he integrated the same with applied statistics and data analytics in trans disciplinary studies in the agricultural and related sectors focusing on the interface between biophysical \& social sciences. Davies has over 26 years' experience in participatory and action research; designing, implementing, monitoring and evaluating rural development interventions; data collection and statistical data analysis. Davies has vast experience with research in Eastern, Horn of Africa and Southern Africa. Similarly Davies has wide experience in training rural development workers (extension staff) in sustainable agriculture and implementing Projects in smallholder settings. He has a pioneer work in adapting farmer field schools for farmer empowerment, learning and participatory research in smallholder tea-based mixed farming systems of Eastern, Southern and Western African Countries.

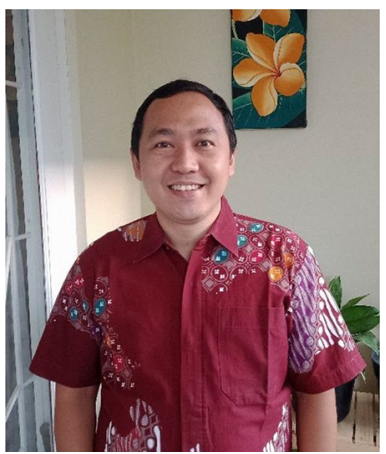

Deddy Heriyanto is a consultant and researcher with more than 15 years' experiences in impact evaluation researches for the development sectors. He has extensive experiences in conducting evaluation research for projects carried out by national and international NGOs in Indonesia and Timor Leste, covering the topics of livelihood and agriculture, water and sanitation, disaster management and youth economic empowerment. He has strong quantitative $\&$ analytical skills with educational background in Business \& Management (BSc) and master degree in Social Psychology from Gadjah Mada University, Yogyakarta, Indonesia. Currently, Deddy Heriyanto serves as Director of CIRCLE Indonesia, a Cooperative Consultant Firm based in Yogyakarta, for the period 2017-2023.

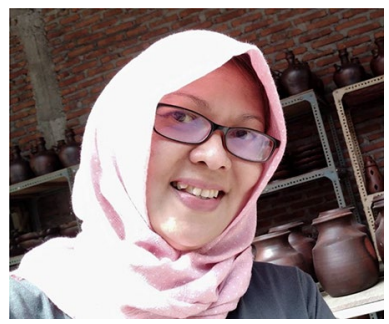

Sukma Tin Aprillya holds BSc (Agriculture) from Lampung University and Master Degree (in Participatory Development) from Davao Medical School Foundation, Philippines. She is currently a senior consultant at CIRCLE Indonesia. She has over 15 years of experience in providing services in terms of consultancy and training for varying national and international development agencies. She is also having extensive experiences in conducting research, especially in terms of monitoringevaluation and impact assessment on sustainable livelihood, sustainable agriculture, food security and agricultural commodities sectors. In addition to the consultant and researcher, she is also an experienced program and project manager in public health sector with the ability to initiate, manage cross-functional teams, multi-disciplinary and multicultural team that consist of hundreds of persons and key partners in Indonesia.

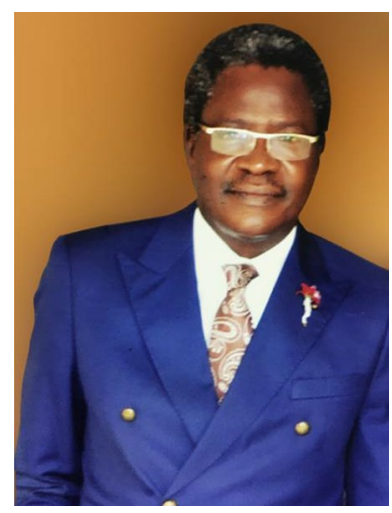

Alhi N'Guessan Mr. N'Guessan started his career in 1986 as regional manager of AIESEC International in Brussels. In 1986 and 1987 , he was a market analyst in the Aerospace division at AMRO Bank (now ABNAMRO). Between 1988 and 1998 , he held several positions in the fields of marketing and management in Europe in Africa, notably at Time Manager International France. It justifies 30 years of experience, the last 20 years of which have been devoted to the development of marketing in the West African Economic and Monetary union). Since 1999, Mr. N'GUESSAN has led missions for several international organizations including the World Bank, the African Development Bank, USAID, JICA, European Union, AFD, BNP Paribas. Mr. N'Guessan is a member of ESOMAR and GALLUP International association.

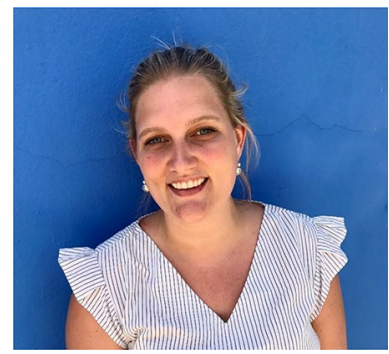

Laura Courbois is a sustainable development professional with a genuine passion for helping people and organizations succeed in their efforts to improve standards of living and foster resilient economies. She has 7+ years of experience working in agri-value chains and inclusive economic development in Southern and Eastern Africa. Her core areas of expertise include monitoring, evaluation, and learning (MEL) and project management. Laura is a Senior Consultant with Imani Development, based in Blantyre Malawi. In this role, she provides technical assistance, advisory services, and MEL support to programmes that drive structural, sustainable change in agricultural commodity sectors and supply chains. Laura holds a Bachelor of Arts in Economics and International Affairs from the University of Wisconsin - Madison and is currently completing a Masters of Science in International Development from the University of Birmingham in the United Kingdom.

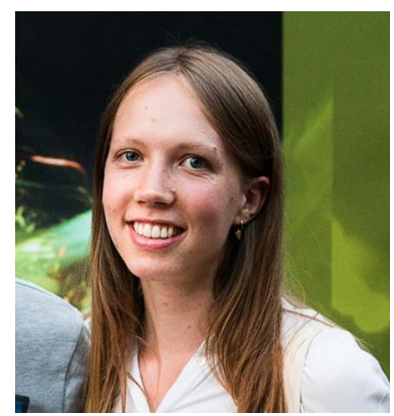

Deborah Bakker is a Research Trainee at Wageningen Economic Research, part of Wageningen University \& Research. She is specialized in land governance for equitable and sustainable development. In addition, she has worked on a number of projects on the resilience of local and global food systems in the face of shocks. Deborah graduated cum laude from the Research Master (MA) in International Relations at the University of Groningen and holds a BSc in Political Science from the Vrije Universiteit Amsterdam. In 2017, she conducted five weeks of field research in northern Sierra Leone, to assess the gendered socioeconomic impacts of large-scale land-based investments for the production of palm oil and food for export. 


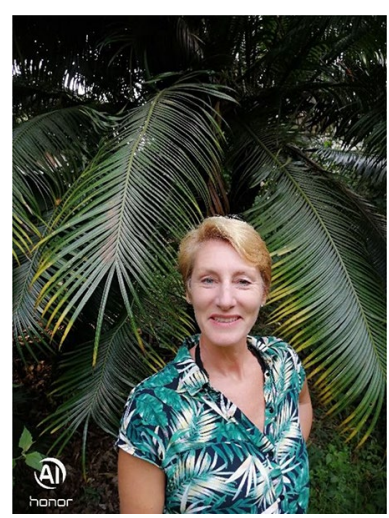

Verina Ingram is social scientist conducting multidisciplinary research for societal impact focusing on the interactions between people, natural resources and markets. She has 25 years of experience working with governments, NGOs, business, researchers and communities in Africa, Europe, Latin America and Asia. Verina works on tropical commodities including cocoa, timber, oil palm, coffee and non-timber products, evaluating the different ways how landscapes and value chains are governed and the tele-

coupled impacts on livelihoods and ecosystems. Verina works with Wageningen Economic Research since 2012, and as well with the Wageningen University Forest \& Nature Conservation Policy Group since 2015 . 